\title{
Promoting academic engagement: university context and individual characteristics
}

\author{
Zhiyan Zhao ${ }^{1} \cdot$ Anders Broström $^{2}$ (D) . Jianfeng Cai ${ }^{1}$ \\ Published online: 11 July 2018 \\ (c) The Author(s) 2018, Corrected publication July/2018
}

\begin{abstract}
This paper aims to explore the impact of organizational context on individuals' industry activities in Chinese universities. Academic engagement, which includes collaborative research, contract research, consulting and other informal outreach activities, is posited as being jointly determined by organizational and individual level factors. Based on 564 Chinese scientists' survey responses, our results show that scientists perceiving their university as having a strong entrepreneurial mission or supportive policy context are more active in academic engagement. This relationship is, however, moderated by individual-level factors. Specifically, entrepreneurially oriented university missions and supportive policy are more strongly associated with intra-individual differences in academic engagement for junior scientists, and for scientists with established personal networks to industry. Our analysis also shows that several individual-level predictors of academic engagement identified in studies set in Europe and the US carry over to the Chinese context.
\end{abstract}

Keywords Academic engagement · Entrepreneurial mission · Policy context · Individual characteristics

JEL Classification J18 $\cdot$ L52 $\cdot$ O31

\section{Introduction}

As suggested by the idea of "the entrepreneurial university", the missions of universities across the world have broadened from teaching and research to encompass on active focus on academic knowledge transfer. This phenomenon has attracted the attention of both

The original version of this article was revised: The original version of this article unfortunately contained a mistake. The corresponding author's name was incorrect. The given name and family name were interchanged. It should read as Anders Broström. The original article has been corrected.

Anders Broström

andbr@kth.se

1 School of Management, Northwestern Polytechnical University, Xi'an 710072, Shaanxi, People's Republic of China

2 Department of Industrial Economics and Management, KTH Royal Institute of Technology, Stockholm, Sweden 
policy-makers and scholars during the last two or three decades (Bercovitz and Feldman 2006; Bonaccorsi et al. 2010). National and regional governments across the world, along with actors such as the OECD and the European Union, have sought to pave the way for stronger university-industry relationships through formal regulation and reforms, as well as through more informal institutional influence. We are in this paper concerned with the question of how (a set of) organizational-level initiatives arising from such pressure for strengthened exchange with industry translates into individual behavior.

An important insight from recent literature on university-industry relationships is that there exists a diverse variety of channels of academic knowledge transfer (Bekkers and Freitas 2008), with partially different antecedents and consequences. In particular, it has been suggested that commercialization of academic knowledge (i.e. patenting and entrepreneurship), which has received the most intense scholarly and policy-maker attention (Abreu and Grinevich 2013; Hunter et al. 2011; Jain et al. 2009; Jensen and Thursby 2003; O'Shea et al. 2008), are imbedded in a partially different context than activities such as consulting, joint research, contract research an informal networking. Moreover, several studies (Caldera and Debande 2010; Cohen et al. 2002; D'Este and Patel 2007; Iorio et al. 2017; Schartinger et al. 2001) have pointed out that such activities, which were named academic engagement by Perkmann et al. (2013), are significantly more widespread and may play equally if not more important roles for knowledge transfer than research commercialization in the traditional sense. Studies from several different national settings have repeatedly confirmed that a large majority of firms perceive universities as primarily a source of information to enhance their absorptive capacity or develop innovation capabilities in an indirect route through consulting and contract research (Motohashi 2006; Broström et al. 2009; McKelvey and Ljungberg 2017; Shi et al. 2008; Zhou 2005; Zhou et al. 2011; Wu and Zhou 2012).

Prior research on academic engagement from the university perspective has mainly focused on the effect of individual determinants of academic engagement such as demographic characteristics, academic status, industry network, scientific output, and experience (Bekkers and Freitas 2008; Boardman and Ponomariov 2009; D'Este and Patel 2007; D'Este and Perkmann 2011; Giuliani et al. 2010; Haeussler and Colyvas 2011; Ponomariov 2008). Several studies on the wider phenomenon of academic knowledge diffusion have gone beyond the individual-focused perspective to examine the role of the organizational context (Bercovitz and Feldman 2008; D'Este and Perkmann 2011; Friedman and Silberman 2003; Huyghe and Knockaert 2015; Siegel et al. 2003; Munshaw et al. 2018). However, only a limited few such studies (D'Este and Patel 2007; Haeussler and Colyvas 2011; Ponomariov 2008; Tartari et al. 2014) focus on academic engagement. There is, as of yet, therefore no firmly established set of research results on how and when the organizational context promotes, facilitates or hinders academic engagement. We also note that empirical evidence on this issue is almost exclusively drawn from Western settings.

In this paper, we investigate the role of how scientists perceive their organizational context for their engagement with industry. Our study is empirically set in China. To the authors' knowledge, this is the first study to investigate the role of organizational factors for academic engagement in the Chinese context. Understanding the role of the organizational context for academic engagement in China is important for furthering our understanding of university-industry interaction in China. Since Chinese universities have characteristics which are different from Western countries, findings from Western contexts may not be fully valid for Chinese universities (Wu 2010). Typically, Chinese universities, as in most developing countries, are not seen as playing crucial roles in emerging technology or commercialization in a global context (Wu and Zhou 2012). While this gap towards the West is gradually being reduced, e.g. as a consequence of an increasing policy focus on improving 
their academic excellence in recent years, it remains in place. Furthermore, the combination of strong emphasis on the industrial relevance of public research and the close integration between universities and the Chinese nation-state through the influence of the ruling Communist party and the deeply rooted culture of collectivism creates a markedly different framework for academic engagement than that of most Western economies.

We argue that the organizational context is likely to play an important role in shaping scientists' industrial activities in Chinese universities. In particular, we follow Wu (2010) in considering the entrepreneurial orientation of a university's mission and policy context as key dimensions of the organizational context relevant for university-industry relationships in China. Our study examines how these two factors influence academics' interaction with industry. Furthermore, we also explore the potentially moderating roles of individual-level characteristics.

In the following sections, we introduce a theoretical background for analysis of academic engagement and develop hypotheses about the role of the institutional environment in shaping individuals' behavior. Next, we present a description of the sample and methodology, followed by empirical results. The paper concludes with a discussion of results, implications, limitations and future research directions.

\section{Theoretical framework and hypotheses development}

Academics' revealed preference for engagement with industry may be understood as affected by both their own interest for such activities (supply of academic engagement), and by their ability to engage on sufficiently favorable terms. The latter can also be expressed as the level of interest of external actors in acquiring the services of a specific academic (demand for academic engagement). Both interest and ability are quite naturally varying between individual academics. In this study, we are primarily interested in understanding how the institutional environment affects the industrial engagement of scientists.

In developing the organizational perspective, we primarily draw on institutional theory and academic capitalism research to develop a view of how academics' interest in developing industrial relations are affected by their institutional environment. We do, however, recognize that organizational-level factors and initiatives may also affect academic scientists' ability to engage with industry, e.g. by offering facilitation of contacts between firms and scientists.

Work in the tradition of "new institutionalism" stresses that organizations shape members' behavior by rules, norms, and values (Scott 1987, 2013) and cognition of social and organizational environment affect individuals' knowledge-related behaviors (David and Fahey 2000; Szulanski 1996). Following this perspective, previous studies have employed an institutional perspective to analyze the organizational antecedents of university technology transfer (Colyvas and Powell 2006; Guerrero and Urbano 2012; Huyghe and Knockaert 2015; Lam 2010).

In developing our view about academics' sensitivity to perceived institutional pressure regarding academic engagement, we draw on academic capitalism scholarship. Work in this tradition has acknowledged that decisions in and about academic activities are subject to considerations related to the need to acquire external grants and contracts in competitive environments by the capital they hold (Slaughter and Leslie 1997, 2001). Previous studies (Cohen et al. 1998; Etzkowitz et al. 1998) have examined technology transfer and university-industry relationships from the perspective of academic capitalism. In this study, we adopt a similar perspective to understand contingencies between individuals' career background, their perceptions of their institutional environment and their industry engagement. 


\subsection{Organizational context and academic engagement}

In line with theoretical expectations as of above, we argue that the organizational context shapes scientists' cognition and thereby influences their attitudes towards industrial engagement. Prior studies have demonstrated such patterns at the level of the university, the department, and the research group (Bercovitz and Feldman 2008; Colyvas and Powell 2006; Stuart and Ding 2006). In investigating the interplay between organizational and individual factors in the Chinese context, we choose to focus on university-level factors. We expect university-related factors to have stronger impact in shaping scientists' industry behaviors than idiosyncrasy at other (lower) organizational levels. While significant differences exist across universities, the general control structure is of an hierarchical nature. ${ }^{1}$ For example, although departments may be involved in the process of faculty recruitment and recommend candidates to central administrations, the final decision about recruitment is taken at the central university level. The personnel appointment is usually controlled by a university Party committee (zuzhibu) in Chinese universities. Policies about professional promotion are also dictated by the central administration, and employees and local departments are expected to fully support these policies (Sun and Gu 2017).

Previous research on university-level determinants of academic engagement based in Western countries has shown that organizational structures (Bozeman and Gaughan 2007) as well as entrepreneurial orientation (Kalar and Antoncic 2015) and local norms (Haeussler and Colyvas 2011) are important constituents of organizational behavior in terms of direct industrial engagement. In this study, we build on this literature in examining the effect of organizational-level factors on academic knowledge diffusion. Following Wu (2010), we focus on the distinct concepts of an entrepreneurially oriented university mission and university policy context. The concept of mission reflects the beliefs and ideologies of organization (Swales and Rogers 1995). Specifically, an entrepreneurially oriented university mission refers to a position where academic engagement is advanced as a key objective in its own right and as an important aspect of teaching and research (Guerrero and Urbano 2012). An entrepreneurially oriented university policy context refers to university-level practices implemented to realize an entrepreneurial mission. Important elements of such policy are (1) the extent to which resources are dedicated to active support of academic engagement, e.g. through technology transfer and industry liaison offices, (2) the extent to which academic engagement activities are integrated into standards for promotion and individual appraisal, and (3) the regulation of how any direct pecuniary benefits of academic engagement are distributed between the individual scientists and the university.

\subsubsection{University mission and academic engagement}

The Chinese government has been implementing strategies to enhance national innovation capabilities from the economic reforms in 1979 by promoting university knowledge spillovers. A clear directive, which encourages university knowledge transfer as a major mission of universities, was promulgated by the Ministry of Education in $2002 .^{2}$ This change was

\footnotetext{
1 Similar to their counterparts in several other countries, Chinese universities are subject to the direct control of the state. Both in terms of regulations and resource provision, political decisions set the terms under which universities operate.

2 This directive was confirmed after a series of drastic debates around whether university knowledge transfer should be the central mission of universities. These debates were endorsed by Vice Premier Li Lanqing
} 
strengthened by the new policy of "Mass Entrepreneurship and Innovation" published by the central government in $2015 .^{3}$ In response to the increasing pressure from government, Chinese universities have been transforming their missions to emphasize contributions to the national and local economies alongside strictly academic objectives. Nonetheless, similar to Western universities (Ambos et al. 2008; Philpott et al. 2011), significant inter-university differences in terms of culture and mission prevail.

We expect an entrepreneurially oriented university mission to influence the observed level of academic engagement. As articulated by institutional theory, the organizational context affects individuals' behaviors (Oliver 1991; Tolbert and Zucker 1999). More specifically, values expressed in organizational missions are expected to affect the prioritization and execution of activities in organizations (Bart 1996; Smith et al. 2001).

A university with a strong entrepreneurial mission would stress the function of economic and social development, e.g. in linking research and teaching activities more tightly to the perceived needs of industry (Etzkowitz 2003; Guerrero and Urbano 2012). It can therefore be expected that scientists (and scientific activities) in universities with pronouncedly entrepreneurial mission on average are more oriented towards problems of contemporary industrial relevance. Previous studies have also pointed out that the extent to which scientists perceive that their university embraces knowledge transfer activities affects their industry activities, both as regards breadth and depth of university knowledge transfer (Iorio et al. 2017; Kalar and Antoncic 2015; O'Shea et al. 2005). ${ }^{4}$

In summary, we argue that being embedded in an academic organization with a supportive entrepreneurial environment will increase academic's interest in knowledge diffusion activities (Kenney and Goe 2004). More positive attitudes is likely to alleviate some of the 'mismatch' problems between university research and industry demand such as have been found to exist both in China and in the West (Lööf and Broström 2008; Wu and Zhou 2012). We therefore expect entrepreneurial mission to be positively associated with industrial activities and put forward our first research hypothesis as follows:

H1a: Scientists perceiving their university as having an entrepreneurial mission are more active in academic engagement.

\subsubsection{University policy context and academic engagement}

Both Western and Chinese scholars have studied the policy context of universities as regards technology transfer or knowledge diffusion activities. The policy context is on the hand related to support structures such as technology transfer offices (TTOs), on the other hand to the incentive structures of universities. From the perspective of academic capitalism, supportive policy factors are expected to positively influence academics' interest in academic engagement, whereas academic engagement may be inhibited in a university with no such policy in place (O'Shea et al. 2008; Stuart and Ding 2006). In terms of incentives

Footnote 2 (continued)

and closed with a clear official position which states that universities' major missions are teaching, research, and knowledge transfer (Chinese University Technology Transfer, October 2002).

3 See "several policies and measures of the State Council about vigorously advancing Mass Entrepreneurship and Innovation", National Issue, 2015, No. 32.

4 Notably Munshaw et al. (2018) find no significant associations between US life science academics' perceptions of their university's entrepreneurial mission and their patenting activity. 
for academic engagement and entrepreneurship, a series of factors have been identified. These include policies on royalties and equity (Jensen and Thursby 2003; Thursby and Thursby 2004), policies for distribution of income from commissioned research projects between academics and their universities (Gregorio and Shane 2003; Link and Siegel 2007; Liu and Jiang 2001; Ponomariov 2008; Wu 2010), and the value attributed to industrial engagement and research commercialization in academic promotion processes (Wright et al. 2008; Wu 2010).

Universities with supportive policies can also strengthen academic engagement by actively facilitating scientists' industrial activities (O'Shea et al. 2007; Roberts 1991). For example, sophisticated TTO functions may reduce the search and negotiation costs of scientists interested in getting engaged in contract research, collaborative research or consulting with industry partners in a competitive environment (Wright et al. 2008). It is furthermore possible that firms all other things equal prefer to work with scientists who are active in universities which have established a relevant support structure for academic engagement (Etzkowitz 2004).

From the above considerations, we hypothesize that:

H1b: Scientists perceiving their university as having supportive policy in place are more active in academic engagement.

\subsection{Moderating effects of individual characteristics}

A large body of literature has indicated that individual factors play a much more important role than organizational characteristics in explaining the variation in scientists' industrial engagement activities (D'Este and Patel 2007; D'Este and Perkmann 2011; Perkmann et al. 2013; Ponomariov 2008). A number of studies have also gone on to examine moderating mechanism between individual and organizational determinants (Haeussler and Colyvas 2011; Ponomariov 2008; Tartari et al. 2014). Following this perspective, we explore how seniority and industry networking may moderate the relationship between an entrepreneurial university mission and policy context and academic engagement. Specifically, we explore how the relationship between organizational support for industrial relationship and individual academic engagement may be expected to vary between (groups of) scientists.

\subsubsection{The impact of seniority and organization context}

More senior scientists have been found to engage more actively with industry than their junior colleagues (D'Este and Perkmann 2011; Haeussler and Colyvas 2011; Tartari et al. 2014). This can be explained both by that their expertise may be more highly demanded by industry, but at least in part also by the existence of trade-offs between (certain forms of) industrial collaborations and the demands of academic careers.

Scientists in universities are continuously evaluated by different professional bodies as a basis for distribution of resources and for promotion assessments (Wood 1990). Competition for professional status in academia has in recent times intensified because of the introduction of more stringent requirements. This pressure plays out different for junior and senior scholars. Established professors are usually able to maintain their basic income and scientific prestige while engaging in industrial activities (Lam 2007), while junior scientists are more concerned about promotion and unwilling to involve in knowledge diffusion activities for the risk of delaying their research and publication process (Thursby 
and Thursby 2004). The role of organizational factors in facilitating academic engagement may, as a consequence, vary with individuals' academic status. Tartari et al. (2014) study the social influence between academic peers in the UK, and find that the behavior of colleagues affects early career individuals' engagement in outreach activities more than it affects senior scholars. Furthermore, star scientists are less susceptible to peer influence. Similar evidence is reported in a study of German biotech scientists (Aschhoff and Grimpe 2013), who find that peer influence on industrial involvement decreases with academics' age.

Supportive university contexts, specifically highly entrepreneurial mission and supportive policies, can be expected to decrease the gap between senior and junior scientists in industry engagement. We base this expectation on two assumptions. The first of these is that junior scientists, as argued above, in general have lower ability and lower interest in working with industry than their senior peers. This may also be expressed so that junior scientists are facing above-average search costs and opportunity costs for academic engagement. Our second assumption is that at universities with pronounced support for academic engagement in mission and policies, costs of these types are reduced proportionally for all scientists. These assumptions lead to differential impact on both the interest in and ability for industrial engagement of academics.

Furthermore, we expect that differences in promotion incentives and other supportive measures across universities would primarily affect junior scientists. In universities with a largely 'traditional' mission, where academic engagement is not seen as a core task of academic staff, junior scientists generally have to focus their efforts on teaching and research performance in order to prevail in the professional competition and to achieve promotions. The behavior of senior scientists, who have already reached a certain degree of professional security and hold more social capital, is in general less sensitive to the organizational-level incentive structures.

Furthermore, we expect that service and assistance from TTOs could partially compensate for juniors' shortages in networks, and for relative disadvantages in terms of status, reputation and expertise. Senior scientists, which are on average more well-endowed in these regards, would have less need for support. Such support decreases the relative disadvantage of juniors in terms of the ability to engage with industry of junior academic.

Following the above analysis, we postulate that junior scholars' attitudes towards industrial engagement are more strongly affected by an entrepreneurially oriented university mission than that of their senior peers. Junior scholars are also more strongly than seniors affected both in terms of interest and ability for industrial engagement by the policy context of the university.

In summary, we hypothesize that:

H2a: The relationship between entrepreneurial university mission and academic engagement is weaker for individuals with high academic rank

H2b: The relationship between supportive university policy context and academic engagement is weaker for individuals with high academic rank.

\subsubsection{The impact of industry networking and organization context}

Previous research has demonstrated that scientists' previous working experience with industrial firms is strongly associated with further academic engagement (Bekkers and 
Freitas 2008; D'Este and Patel 2007). Similarly, scientists' affiliations with external organizations have been found positively related to industry interactions (Corley and Gaughan 2005; Hetzner et al. 1989). Both affiliations and previous industry experience are likely to reflect individual scientists having stronger networks with industry than their colleagues, resulting in more participation in collaborative activities.

China is a relationship-based society (Liu and Jiang 2001). The notion of Guanxi, which refers to relationships with other people that an individual maintains, performs a critical function in Chinese social life (Gold et al. 2002; Tsui and Farh 1997). An individual's personal network of industrial connections is therefore likely to play an accentuated role in determining the assignment of industrial contracts to Chinese scientists. Seeking to clarify the relationship between individual and organizational factors in academic engagement in China, we next turn to an analysis of whether the university mission and policy are likely to complement or substitute individuals' personal industrial network in shaping individual scientist's engagement with industry.

A university mission emphasizing industrial relevance and direct interaction with industry, and university policy supporting such activities, may be thought of as catalytic factors in translating an ability to engage with industry into active engagement. In particular, the organizational context may affect to what extent an academic with a personal industrial network utilizes this network for further interaction. With stronger support from the TTO, greater incentives in terms of promotion and monetary rewards, academics are likely to be more prone to accept offers of industry contracts, or to actively pursue such opportunities. Parallel arguments suggest that when academic knowledge diffusion and engagement is more strongly aligned with the institutional mission, more practical implications research outcomes will be generated (Guerrero and Urbano 2012). This advantage will likely be enhanced if academics have external networks.

In terms of our research framework, the above arguments would suggest a positive moderation between our two organizational-level factors (entrepreneurial university mission and policy context) and individual-level proxies for well-developed industrial networks (industry affiliation, industry experience) in predicting academic engagement. But we could also see reasons to expect a negative moderation. With similar assumptions as those developed for hypothesis 2, we would expect (1) that individuals with no personal networks in industry are on average facing higher search costs than their peers with such experience, and (2) that at universities with pronounced support for academic engagement in mission and policies, costs of this type are reduced proportionally for all scientists. That is, individuals' personal networks would be seen as substitutes for university-level initiatives such as TTOs. Furthermore, it could be argued that expectations on academics to engage with industry, such as manifested in organizational mission and in the policy context, would more strongly be affecting those individuals who are not able to demonstrate their 'relevance' through active affiliations or a history of industrial work.

We have no a priori expectation on the relative strength of the positive and negative relationships outlined above. Either one may dominate the other, or they may cancel each other out. Consequently, we do not have a clear hypothesis, but construct our empirical analysis around four questions:

Q1: Is the relationship between (a) entrepreneurial university mission, and (b) supportive policy and academic engagement stronger or weaker for individuals with active industry affiliations? 


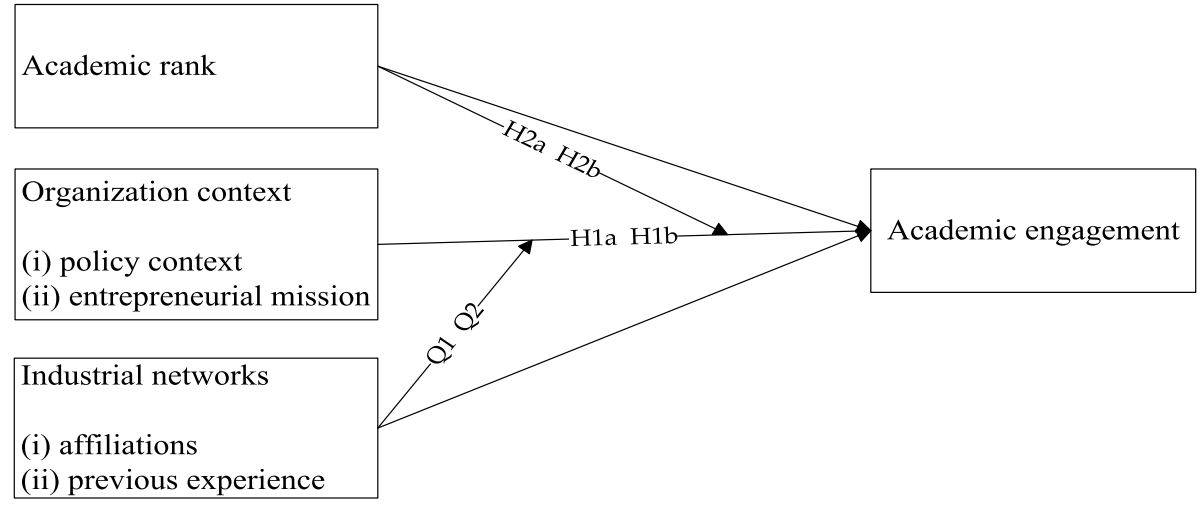

Fig. 1 Theoretical framework

Q2: Is the relationship between (a) entrepreneurial university mission, and (b) supportive policy and academic engagement stronger or weaker for individuals with significant industrial working experience?

Figure 1 illustrates our theoretical framework as developed throughout this section.

\section{Methodology}

\subsection{Data collection and sample}

In order to evaluate the hypotheses and questions developed above, we draw on cross-sectional data collected from March to July 2016 in Chinese universities through an online survey. Most questions and answers used in the survey were adopted from previous studies done by Western researchers. In a few instances, questions and answering scales were adjusted so as to be more suitable for Chinese cultural environment and to avoid conceptual vagueness and item ambiguity.

A pilot survey was conducted in a group consisting of 50 scientists. This was aimed to enquire comments on the questionnaire itself. Invitations to participate in the finalized survey were sent via email. Addresses were collected from official website of respondents' universities, and small part were obtained through mobile tools. A reminder email was sent if we did not get a response after 1 week.

Respondents were selected from the list of universities published by the Ministry of Education of China (MoE 2016). Considering the huge population of researchers in Chinese universities, we focused data collection to universities and university colleges in the Shaanxi province. This province has publicly employed 42,271 university scientists working in 93 higher education institutions (MOE 2016). Different tiers of Chinese universities and colleges, including " 985 " and " 211 " project universities, key universities, ordinary universities, private colleges and specialized colleges. ${ }^{5}$ were targeted by the survey.

\footnotetext{
5 The "985" project was initiated in 1998 by the Chinese central government and aimed to promote Chinese top universities into world-class universities. The " 211 " project refers to universities which the Chinese government plan to develop in 21 st century. Key universities were recognized as prestigious and which
} 
In addition, since this study aimed to explore the effect of organizational context on individual behaviors, we collected data through following several steps in order to confirm the diversity of context. First, 10 respondents in one department received a request to complete an online questionnaire. Another set of 10 respondents in the same department were contacted if there was no response returned within 1 week. This procedure was repeated until we received at least 5 valid responses or until all members in the department had received a request. In total, 5758 requests were sent out and 564 complete questionnaires were returned in our final sample.

$T$-tests indicated no significant differences $(p \geq 0.005)$ between completed and non-completed responses, or between early and late respondents, in terms of gender, academic rank, cross-organization position and industry experience. This indicates that non-response bias was unlikely to be a major problem in our sample (Hair et al. 2010). Tables 6 and 7 in Appendix 1 provide details.

\subsection{Measures}

\subsubsection{Dependent variables}

The questionnaire asked respondents the frequency of 11 types of academic engagement activities (see Table 8 in Appendix 1) in 2014 and 2015. Following D'Este and Patel (2007), the question was constructed with 5 interval response options ( 0 times; $1-2$ times; 3-5 times; 6-9 times; and above 10 times). We used two methods to construct dependent variables for this study from responses to these questions.

The first (main) measurement, which was developed by Bozeman and Gaughan (2007), examines the degree of scientists' industrial engagement by constructing an academic engagement index - a continuous variable with the value range [0, 36.29].

To build the academic engagement index variable, we constructed the difficulty degree of each type of engagement activity. The difficulty degree of each activity presents the proportion of respondents who did not engage this kind of activity in 2014 and 2015. It is calculated as follows:

$$
d_{j}=1-\frac{\sum_{n=1}^{N} b_{n, j}}{N}
$$

where $j=1 \ldots 11$ was the type of engagement; $\mathrm{N}$ was the size of sample which was 564 in this study; $b_{n, j}(0=$ no, $1=$ yes $)$ meant whether the researcher $n$ had engaged in type $j$ engagement. The difficulty degree of each activity is listed in Table 8 in Appendix 1. Then, the academic engagement index is computed as follow:

$$
E_{n}=\sum_{j=1}^{11} d_{j} T_{j}
$$

Footnote 5 (continued)

received a high level of support from the Chinese central government. Ordinary universities mean other universities which are funded by government and have qualification of awarding bachelor degrees. Private colleges refer to colleges which are funded by private sources. Specialized colleges are institutes which only can grant college degrees (MOE 2015). 
where $T_{j}$ denotes the average of each interval options which are $0,1.5,4,7.5$ and 10 respectively.

The second (alternative) dependent variable that we construct reflects the variety of individual industry engagement by computing the number of types of respondents involved in 11 kinds of industry engagement activities. The value range is $[0,11]$. We use this second measure for a robustness check.

\subsubsection{Organizational-level variables}

In this study, we use individuals' perception of university environment to measure entrepreneurial mission and policy context (Hunter et al. 2011; Kalar and Antoncic 2015; Munshaw et al. 2018). We see three important advantages with basing our main measures of mission and policy on the assessment of individual academics, rather than on information collected directly from the university administration. First, it is notoriously difficult to validate the reliability of official documents produced by an organization such as a university, and to code mission statements into ordinal assessments of issues such as to what extent a particular university embraces and supports industrial engagement. Secondly, while differences in academics' perceptions of their university environment are expected to reflect existing differences in the mission and policy of universities (Lam 2010), individuals' perception of these organizational characteristics may vary due to differing knowledge and attitudes. If such individual differences co-vary with the attributes that are key to our study (academic rank, industrial background and affiliations), utilizing externally validated measurements of mission and policy would bias our investigation (i.e., we would not be able to distinguish between results driven by differences in perception and results driven by differences in the sensitivity to these perceptions). Thirdly, perception-based measures of organizational-level phenomena has the advantage that within-organizational differences are fully or partially discounted. That is, if the faculty or department of the individual is markedly more engaged in industrial activities and/or receive greater levels of support for such activities than other parts of the university, such differences will likely affect individual's assessments. Thereby, within-organizational differences which would otherwise give rise to measurement/omitted variable bias can be avoided.

In view of these considerations, we construct measures of mission and policy directly from survey questions to individual academics.

University mission Using a methodology developed by Guerrero and Urbano (2012), we measure the entrepreneurial orientation of the university mission through answers to the following survey question: "How do you think of the following items in your university: (1) my university focuses on publishing papers with practical implications; (2) my university focuses on knowledge transfer activities (i.e. patents, licenses, spin-offs and other transfer); (3) my university focuses on contributing to regional and social development; (4) my university focuses on promoting an entrepreneurial culture; (5) my university focuses on generating entrepreneurs. Each item was associated with a 5-points Likert scale ranging from " $1=$ totally disagree" to " $5=$ totally agree". We obtained a value for the variable University mission as a weighted sum of factor loadings from exploratory factor analysis (EFA) and the values of each items given by respondents.

University policy In this study, we measure the policy context of universities based on factors identified in previous research on industry engagement in Chinese universities (Wu 2010). These factors are distribution of benefits, promotion process, additional incentives, and both the service and organizational structure of any existing TTOs. We used the 
following question: How do you think about the following policies in your university? (1) My university is well-staffed for university-industry interactions; (2) my university offers sophisticated service for university-industry interactions; (3) I get a reasonable share of income from industrial projects; (4) industrial activities plays a certain role in promotion assessment in my university; (5) there is a specialized administration with clear responsibilities for university-industry interactions in my university. Each item was implemented as 5-point Likert scale, with answers anchored at " $1=$ totally disagree" and " $5=$ totally agree". We constructed the variable University policy from the weighted sum of factor loadings from EFA and the values of each items given by respondents.

\subsubsection{Individual-level variables}

Based on previous literature (e.g. Link et al. 2007), a set of variables capturing the individual characteristics that have been found to be associated with academic engagement were also recorded. Gender was measured by a dummy variable and coded 0 for women and 1 for men. Prior studies indicated that men are more likely to be engaged in collaborative activities with industry than women. Academic rank was measured by constructing a dummy variable coded as " $0=$ assistant or lecturer" and " $1=$ associate professor or professor". The survey also asked whether the respondent is a master supervisor or doctoral supervisor $(0=$ no and $1=$ yes $)$. Being a master or doctoral supervisor often means that an academic has access to student resources, which may be a means for industry engagement in itself (Feller et al. 2002). ${ }^{6}$ Furthermore, both rank and supervisor status do in the Chinese context signal high individual status and ability; factors that are likely to affect industrial firms' evaluation of an academic as potential collaboration partner.

Affiliation $(0=$ no, $1=$ yes) indicates whether the respondent maintains an active position in an external organization. Industry experience was measured by a 5-point scale ranging from " $1=$ totally disagree" to " $5=$ totally agree" which was employed by asking respondent whether they think of themselves as having rich working experience in industry emanating from before 2014. In the Chinese cultural context, personal connections play a very important role in professional activities. We expect scientists' connections with industry to facilitate the formation of cooperative contracts in competitive environments.

Finally, we introduce controls for the scientific productivity and scientific field of the individual. Specifically, respondents were asked about their number of journal Publications and Public grants in 2014 and 2015. Respondents were also asked to identify themselves with either the STEM fields, or with non-STEM fields (i.e. social sciences and humanities). ${ }^{7}$ Previous research has found that scientists in STEM fields are more likely to be active in all kinds of knowledge transfer, whereas scientists in social sciences are more likely to engage in non-commercial activities (Abreu and Grinevich 2013).

\footnotetext{
6 Access to postdoctoral students may for parallel reasons also be conducive for academic engagement. We have not, however, collected data on this issue.

7 The decision to not collect more detailed information about respondents' field of study was based on concerns about preserving the anonymity of the respondents. Given the potentially sensitive subjects of the survey, such concerns were given high priority.
} 


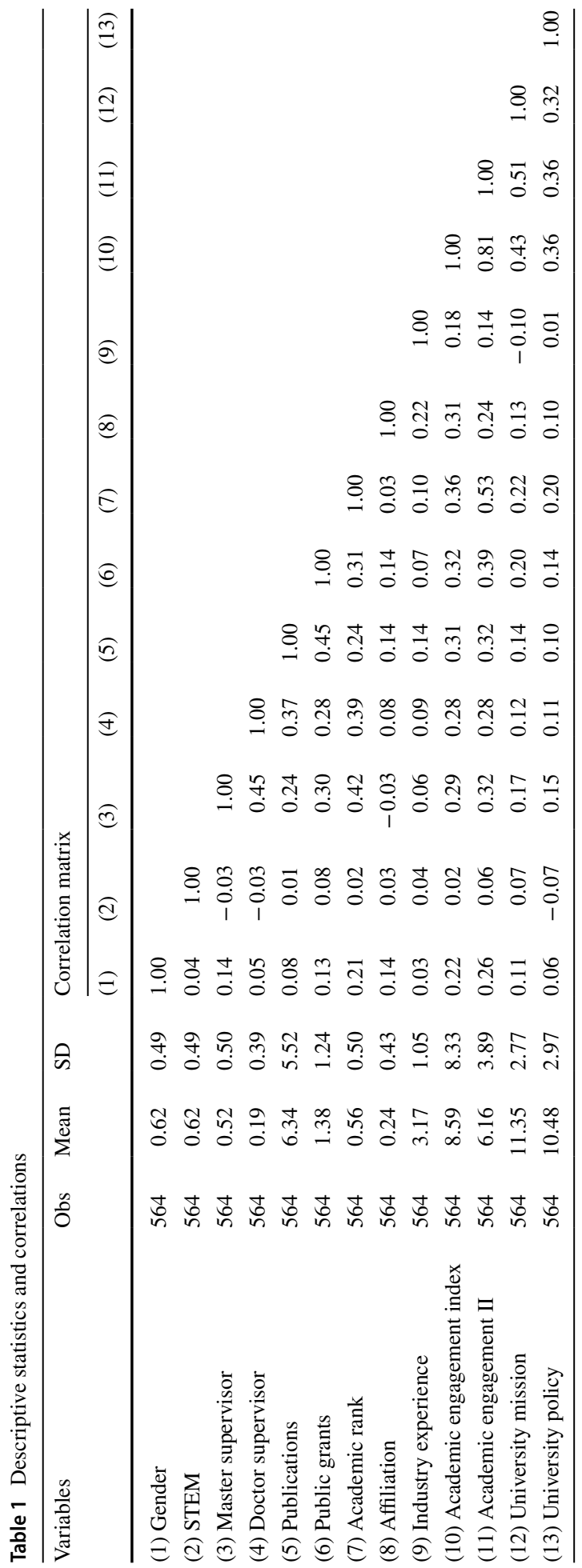




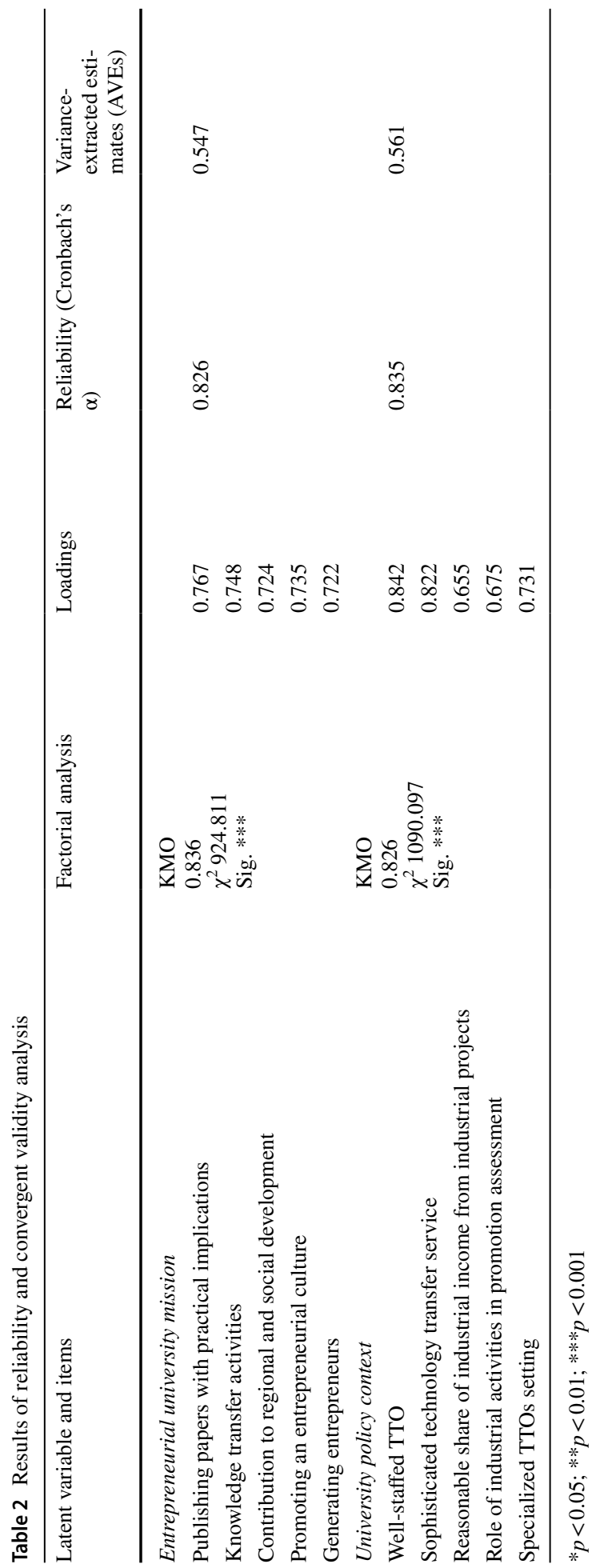




\subsection{Empirical evaluation of the measurement scales}

Tables 1 and 2 provide the technical details of variable construction. Table 1 shows the means, standard deviations and correlation matrix of all variables, before variable centering. As can be seen, our sample consists of 564 respondents. $62 \%$ of them are male and $56 \%$ have an associate professor or professor title. Furthermore, 52 and $19 \%$ of them have master and doctoral students. $24 \%$ maintain a position in industry on the side of their university job.

We furthermore note that correlations between the key dependent variables University mission and University policy and the other dependent variables are limited throughout, which suggests that they may be used in the same model without risking to induce severe multicollinearity issues. In particular, we note that the correlation between University mission and the variable Industry experience is low $(-0.10)$. This finding is somewhat surprising, since it would seem likely that universities emphasizing entrepreneurial values would be more likely to recruit scientists with a background in industry. Possible interpretations are that no such differences exist, or that scientists with a background in industry has a systematically lower perceptions (as driven, for example, by higher expectations) of to what extent their university indeed is entrepreneurially oriented.

We tested the reliability and validity of organizational factors. The detailed results of the reliability analysis, which was performed by SPSS 22 (see Table 2), show that Cronbach's alpha of all scales are above 0.800 . This indicates a satisfactory composite reliability (Cronbach 1951). The results of EFA show that all scales of the KMO (Kaiser-Meyer-Olkin) test statistic are above 0.800 and statistically significant as expected. The variance-extracted estimates (AVEs) for the two variables are 0.547 and 0.561 , which have all exceeded the benchmark of 0.50 , indicating convergent validity of scales (Fornell and Larcker 1981). AVEs are greater than the correlation coefficient between university mission and policy (0.32), which indicates that these two variables are distinguishable constructs. Thus, discriminant validity is supported. Furthermore, in order to check common method variance of our results, a one-factor test was performed by SPSS. The cumulative proportion of variance contribution was $39 \%$, suggesting that common method variance bias was not a major problem in this paper.

\section{Results}

\subsection{Main results}

Table 3 provides the results of eight regression models. Model 1 only includes individual-level variables, and organizational-level variables were added in model 2. Models 3-8 were designed to test the moderating effects of individual factors on organizational factors. We use variable centering to reduce multicollinearity problems. With such corrections in place, the variance inflation factors (VIF) that were computed in each model remain below the critical value of 5 (Hair et al. 2010), indicating that multicollinearity problems do not feature prominently.

Model 1 is the baseline model of individual characteristics and academic engagement. Results show that male academics engage more in industry interactions than their female peers, which is in line with prior research (Azagra-Caro 2007; Bozeman and Gaughan 


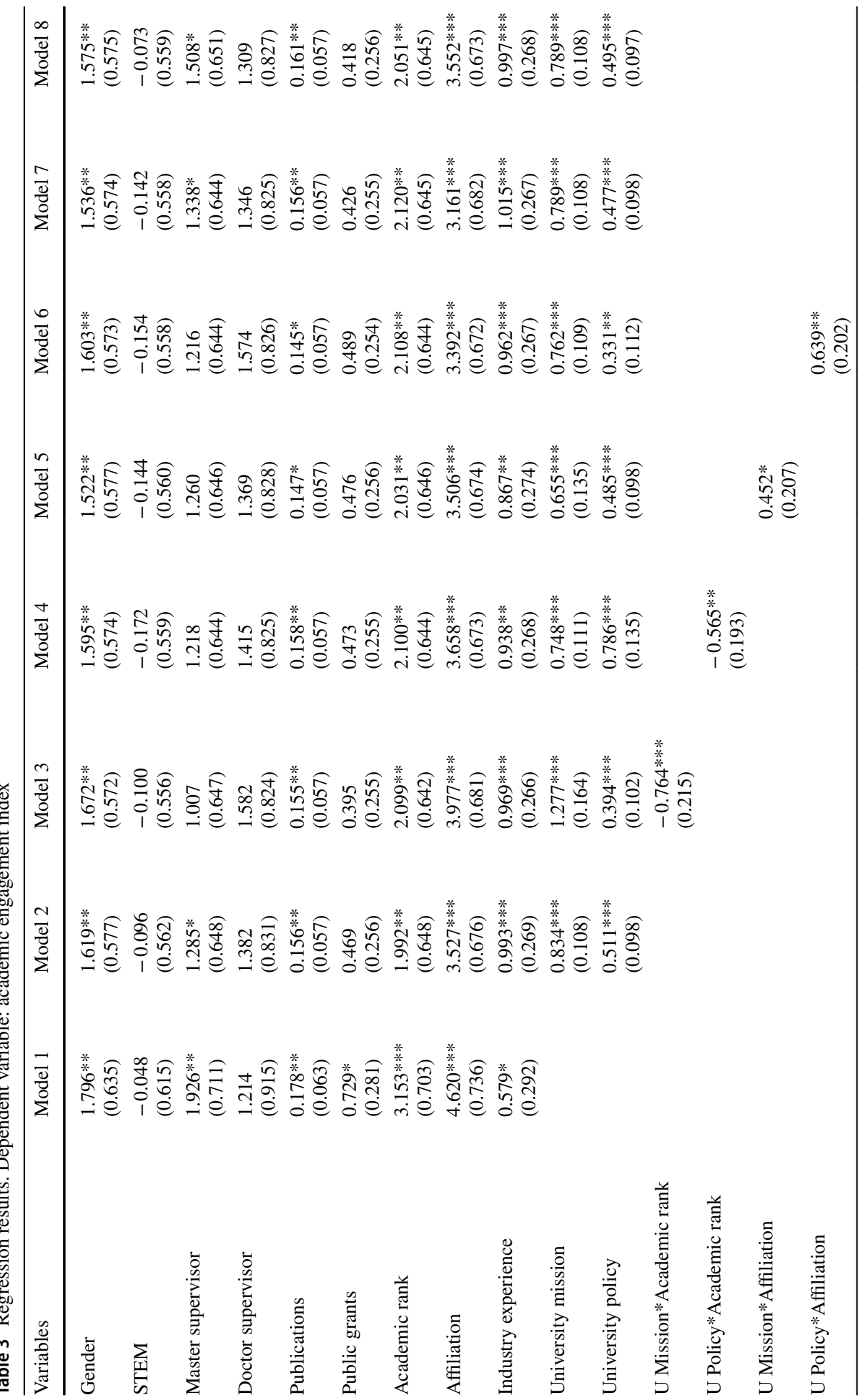




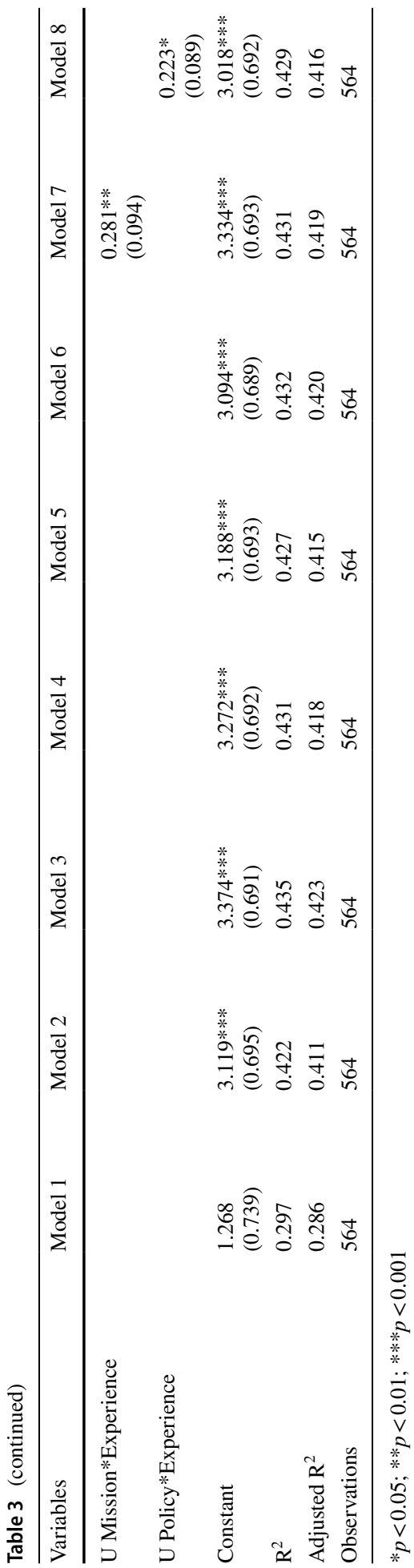

Springer 

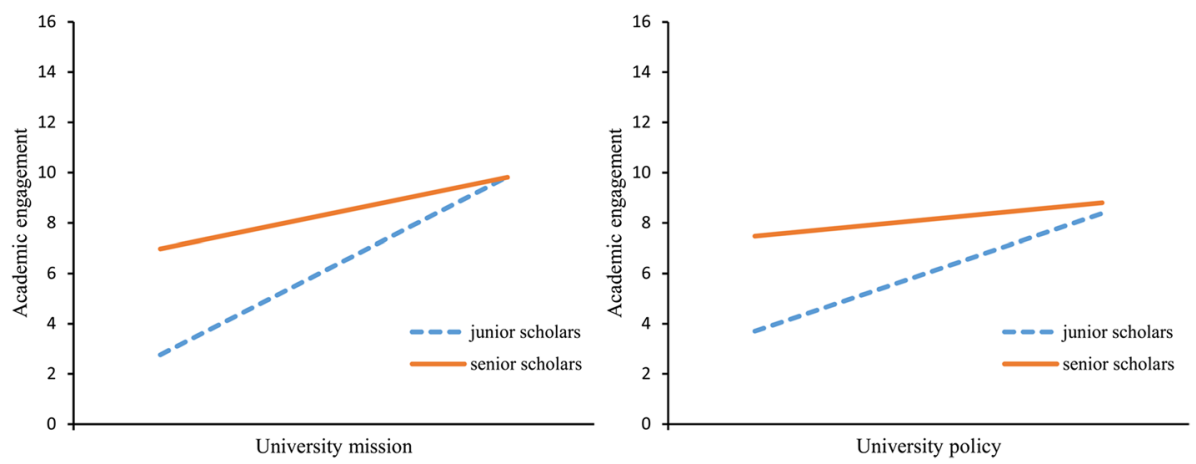

Fig. 2 Moderating effect of Academic rank

2007). Being a master student supervisor has a positive and statistically significant effect. This result likely reflects a specificity of the Chinese university system, where only a select group of faculty are allowed to supervise. Access to master students may provide advantages in terms of resources for conducting industry projects, or to build networks with industry. Academic rank is also proved having a positive and significant which is in line with previous studies (Boardman 2008; D'Este and Perkmann 2011; Ponomariov 2008). Senior scientists generally have greater career security and have more freedom to engage with industry. Scientific productivity, which can be indicative of publications and public funding, has a positive and significant effect on individual engagement, which is also in line with prior research (Boardman and Ponomariov 2009). Together, the results on rank and productivity may also be interpreted as reflecting a preference of industrial firms to engage academics with higher status for projects and interactions. Such an interpretation is also supported by a closer examination of heterogeneity within the group of junior scientists. The most active junior scientists are also more scientifically productive and more well-connected than their peers who do not engage with industry.

Finally, having an affiliation to an external organization also, as expected, has a positive and significant effect on industry interaction. This is in line with Corley and Gaughan (2005). Previous experience positively influences academic engagement, indicating that experienced scientists probably have larger industrial networks which are conducive to building partnership with industry.

We build model 2 based on model 1 by adding variables describing the individual's perception of to what extent the institutional environment encourages and facilitates interaction with industry. The results show that university mission and policy are positively and significantly associated with the dependent variable. Hence, hypotheses 1a and $1 \mathrm{~b}$ are supported.

In models 3 and 4, we allow for moderating effects of Academic rank on the relationship between organizational factors and academic engagement. Coefficient estimates on the interaction variables $U$ Mission*Academic rank and $U$ Policy*Academic rank are both negative and significant, indicating that the industrial activities of junior scientists are more sensitive to organizational context than those of senior scientists'. Thus, hypotheses $\mathrm{H} 2 \mathrm{a}$ and $\mathrm{H} 2 \mathrm{~b}$ are supported. Figure 2 illustrates the moderating effect of academic rank on the impacts of University mission and University policy. The figure demonstrates how senior scholars are more likely than juniors to deviate in a positive sense, i.e. to engage with industry also in the absence of support and active institutional encouragement. 

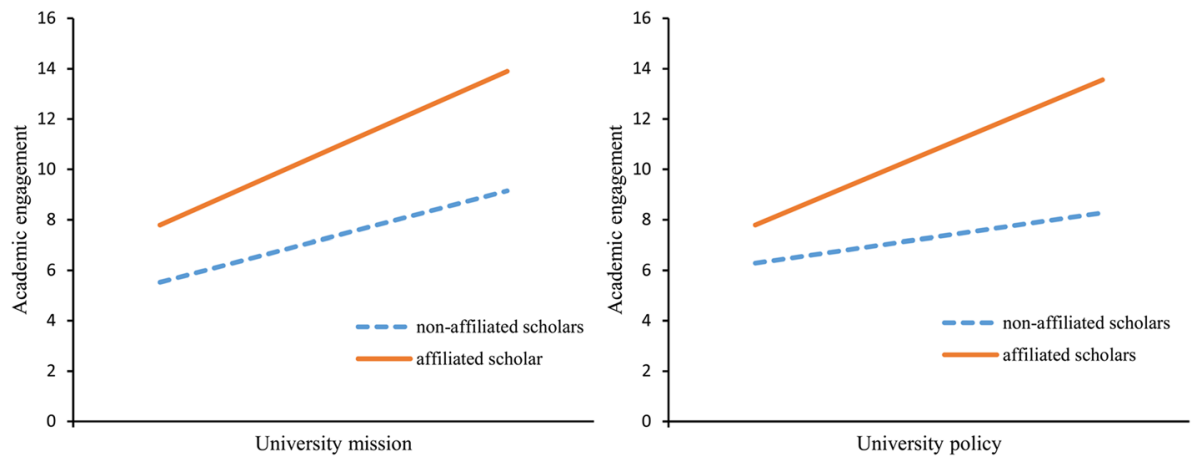

Fig. 3 Moderating effect of Affiliation
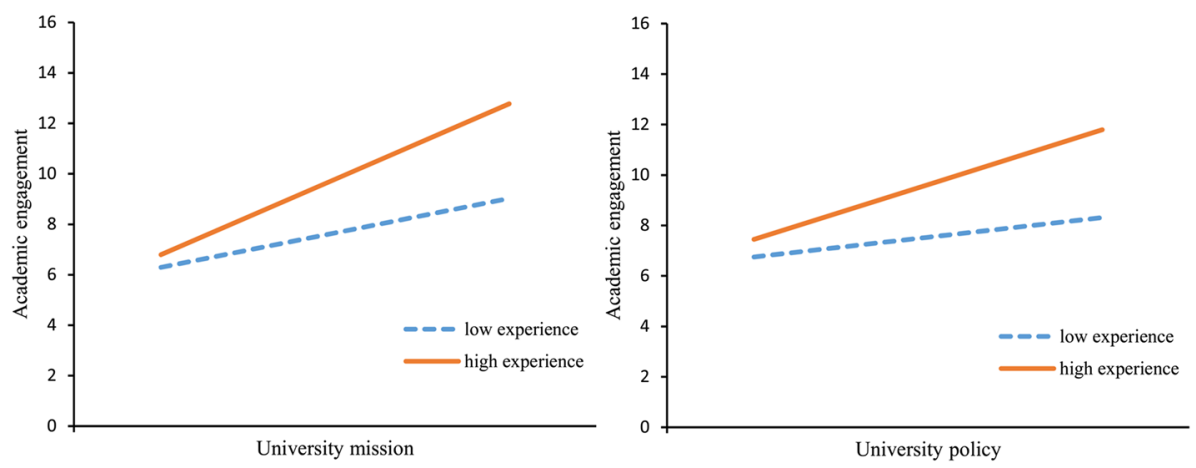

Fig. 4 Moderating effect of Industry experience

In models 5, 6, 7 and 8 we test the moderating effect of having personal connections to industry, in the form of an industrial Affiliation or an industrial background (Industry experience). The coefficient estimates of the interaction terms in all four models are positive and significant, suggesting that complementarity effects between organizational-level factors and individual networks clearly dominate substitution effects. Figures 3 and 4 illustrate the moderating effects of Affiliation and Industry experience on the impacts of University mission and University policy. These results suggest that academics with industrial connections are more strongly affected by organizational-level factors than their peers lacking such connections. The latter group, which may be referred to as 'ivory-tower' scientists are more likely to deviate in a negative sense, i.e. to refrain from academic engagement also when encouraged and actively supported by their university.

\subsection{Robustness to measurement choice}

We also check the robustness of our results to critical choices of measurement. The first of these tests concerns the measure of academic engagement. Since our alternative formulation of the dependent variable is a count of types of scientists engaged in industry activities, we estimate these models with a Poisson estimator. All results remain qualitatively similar as in Table 3 (see Table 9 in Appendix 2). The second set of robustness test 
(reported in Table 10 in Appendix 2) concerns the measure of mission and policy. We have argued that basing such measures on direct assessment by individuals has advantages for our analysis. Clearly, however, the reader may ask to what extent these measures capture individual idiosyncrasy and ignorance rather than circumstances addressable by policy makers. In order to investigate this, we utilize official data on the total amount of revenues flowing into a university from industry, divided by the number of active scientists at that university (Source: Ministry of Education 2016). We run the models of Table 3 using this 'objective' measure of a university's orientation towards industrial activities in place of the variables University mission and University policy. All the results of this analysis all go in the same direction as those of our main analysis. This pattern increases our confidence in our findings as being robust against potential measurement problems.

\subsection{Additional analysis}

Our analysis thus far has straightforwardly analyzed associations between individual perceptions of the institutional environment and engagement with industry. While our findings are generally congruent with our theoretical arguments that such associations can be understood as rational responses external signals and incentives, we acknowledge that there are alternative mechanisms that may generate results similar to those of Table 3. Two sets of tests are conducted in order to gain further insight into the specific mechanisms generating the associations reported above.

\subsubsection{Are differences in observed behavior driven by differences in attitudes?}

We first set out to validate that individuals' perceptions are indeed associated with intention and confidence regarding academic engagement. As elaborated in section two, we expect both University mission and University policy to be associated with individuals' intention to collaborate with industry, and we expect University policy to be associated with individuals' confidence in their ability to collaborate. It is primarily through these associations that we expect individuals revealed preference towards academic engagement to be related to their perception of the institutional environment.

We subject these expectations to direct testing by exploiting data from two additional sets of survey questions. Specifically, survey questions were "How likely are you to engage in the following types of collaborations with industry in the future?" and "How confident are you in successfully engaging in the following types of collaborations with industry?". Collaboration was specified and indexed using the same four types of interaction as used in the main analysis. ${ }^{8}$

Tables 4 and 5 tabulate results. Results do throughout support the associations that were suggested above. Not only is University policy associated with intentions and confidence, but all moderations that were found to affect Academic engagement also found to hold. Similarly, University mission is found to be associated with intentions, with parallel moderations to those of our main results. ${ }^{9}$ We conclude that our main results do indeed seem to reflect how individuals' perception of their institutional environment affect their motivation and abilities for industrial engagement.

\footnotetext{
${ }^{8}$ We found a high degree of consistency between answers within each category. Cronbach alphas were 0.955 for Intention and 0.905 for Confidence.

9 We do not model an individual's confidence to collaborate with industry as a function of university entrepreneurial mission since we do not have any ex-ante rationale to expect such a relation.
} 
Table 4 Regression results. Dependent variable: intention to collaborate with industry

\begin{tabular}{|c|c|c|c|c|c|c|c|}
\hline Variables & Model 1 & Model 2 & Model 3 & Model 4 & Model 5 & Model 6 & Model 7 \\
\hline Gender & $\begin{array}{l}0.117 \\
(0.078)\end{array}$ & $\begin{array}{l}0.125 \\
(0.076)\end{array}$ & $\begin{array}{l}0.096 \\
(0.077)\end{array}$ & $\begin{array}{l}0.107 \\
(0.077)\end{array}$ & $\begin{array}{l}0.114 \\
(0.077)\end{array}$ & $\begin{array}{l}0.114 \\
(0.076)\end{array}$ & $\begin{array}{l}0.111 \\
(0.077)\end{array}$ \\
\hline STEM & $\begin{array}{l}0.051 \\
(0.076)\end{array}$ & $\begin{array}{l}0.052 \\
(0.074)\end{array}$ & $\begin{array}{l}0.041 \\
(0.075)\end{array}$ & $\begin{array}{l}0.045 \\
(0.075)\end{array}$ & $\begin{array}{l}0.045 \\
(0.075)\end{array}$ & $\begin{array}{l}0.040 \\
(0.074)\end{array}$ & $\begin{array}{l}0.054 \\
(0.075)\end{array}$ \\
\hline Master supervisor & $\begin{array}{l}0.132 \\
(0.087)\end{array}$ & $\begin{array}{l}0.089 \\
(0.086)\end{array}$ & $\begin{array}{l}0.127 \\
(0.086)\end{array}$ & $\begin{array}{l}0.139 \\
(0.087)\end{array}$ & $\begin{array}{l}0.127 \\
(0.087)\end{array}$ & $\begin{array}{l}0.120 \\
(0.086)\end{array}$ & $\begin{array}{l}0.165 \\
(0.087)\end{array}$ \\
\hline Doctor supervisor & $\begin{array}{l}-0.072 \\
(0.112)\end{array}$ & $\begin{array}{l}-0.040 \\
(0.110)\end{array}$ & $\begin{array}{l}-0.075 \\
(0.111)\end{array}$ & $\begin{array}{l}-0.077 \\
(0.111)\end{array}$ & $\begin{array}{l}-0.069 \\
(0.111)\end{array}$ & $\begin{array}{l}-0.037 \\
(0.110)\end{array}$ & $\begin{array}{l}-0.083 \\
(0.111)\end{array}$ \\
\hline Publications & $\begin{array}{l}0.014 \\
(0.008)\end{array}$ & $\begin{array}{l}0.014 \\
(0.008)\end{array}$ & $\begin{array}{l}0.012 \\
(0.008)\end{array}$ & $\begin{array}{l}0.014 \\
(0.008)\end{array}$ & $\begin{array}{l}0.014 \\
(0.008)\end{array}$ & $\begin{array}{l}0.012 \\
(0.008)\end{array}$ & $\begin{array}{l}0.015^{*} \\
(0.008)\end{array}$ \\
\hline Public grants & $\begin{array}{l}0.032 \\
(0.034)\end{array}$ & $\begin{array}{l}0.020 \\
(0.034)\end{array}$ & $\begin{array}{l}0.033 \\
(0.034)\end{array}$ & $\begin{array}{l}0.026 \\
(0.034)\end{array}$ & $\begin{array}{l}0.032 \\
(0.034)\end{array}$ & $\begin{array}{l}0.035 \\
(0.034)\end{array}$ & $\begin{array}{l}0.024 \\
(0.034)\end{array}$ \\
\hline Academic rank & $\begin{array}{l}0.372^{* * * *} \\
(0.087)\end{array}$ & $\begin{array}{l}0.387 * * * \\
(0.086)\end{array}$ & $\begin{array}{l}0.380 * * * \\
(0.086)\end{array}$ & $\begin{array}{l}0.388^{* * * *} \\
(0.087)\end{array}$ & $\begin{array}{l}0.381 * * * \\
(0.087)\end{array}$ & $\begin{array}{l}0.393 * * * \\
(0.086)\end{array}$ & $\begin{array}{l}0.380^{* * * *} \\
(0.087)\end{array}$ \\
\hline Affiliation & $\begin{array}{l}0.252 * * \\
(0.091)\end{array}$ & $\begin{array}{l}0.325 * * * \\
(0.091)\end{array}$ & $\begin{array}{l}0.247 * * \\
(0.090)\end{array}$ & $\begin{array}{l}0.205^{*} \\
(0.092)\end{array}$ & $\begin{array}{l}0.265^{* *} \\
(0.091)\end{array}$ & $\begin{array}{l}0.227^{*} \\
(0.090)\end{array}$ & $\begin{array}{l}0.256 * * \\
(0.090)\end{array}$ \\
\hline Industry experience & $\begin{array}{l}0.177 * * * \\
(0.036)\end{array}$ & $\begin{array}{l}0.174 * * * \\
(0.036)\end{array}$ & $\begin{array}{l}0.150 * * * \\
(0.037)\end{array}$ & $\begin{array}{l}0.180^{* * * *} \\
(0.036)\end{array}$ & $\begin{array}{l}0.172 * * * \\
(0.036)\end{array}$ & $\begin{array}{l}0.171^{* * *} \\
(0.036)\end{array}$ & $\begin{array}{l}0.178^{* * *} \\
(0.036)\end{array}$ \\
\hline University mission & $\begin{array}{l}0.424 * * * \\
(0.056)\end{array}$ & $\begin{array}{l}0.699 * * * \\
(0.084)\end{array}$ & $\begin{array}{l}0.276 * * * \\
(0.069)\end{array}$ & $\begin{array}{l}0.401^{* * * *} \\
(0.056)\end{array}$ & $\begin{array}{l}0.390 * * * \\
(0.057)\end{array}$ & $\begin{array}{l}0.373^{* * * *} \\
(0.056)\end{array}$ & $\begin{array}{l}0.398 * * * \\
(0.056)\end{array}$ \\
\hline University policy & $\begin{array}{l}0.351 * * * \\
(0.051)\end{array}$ & $\begin{array}{l}0.278 * * * \\
(0.053)\end{array}$ & $\begin{array}{l}0.329 * * * \\
(0.051)\end{array}$ & $\begin{array}{l}0.334 * * * \\
(0.051)\end{array}$ & $\begin{array}{l}0.459 * * * \\
(0.071)\end{array}$ & $\begin{array}{l}0.223 * * * \\
(0.058)\end{array}$ & $\begin{array}{l}0.342 * * * \\
(0.051)\end{array}$ \\
\hline $\begin{array}{l}\text { U Mission*Academic } \\
\text { rank }\end{array}$ & & $\begin{array}{l}-0.475^{* * *} \\
(0.110)\end{array}$ & & & & & \\
\hline U Mission* Affiliation & & & $\begin{array}{l}0.376 * * * \\
(0.106)\end{array}$ & & & & \\
\hline U Mission*Experience & & & & $\begin{array}{l}0.137 * * \\
(0.049)\end{array}$ & & & \\
\hline U Policy*Academic rank & & & & & $\begin{array}{l}-0.220^{*} \\
(0.101)\end{array}$ & & \\
\hline U Policy*Affiliation & & & & & & $\begin{array}{l}0.454 * * * \\
(0.104)\end{array}$ & \\
\hline U Policy*Experience & & & & & & & $\begin{array}{l}0.128 * * \\
(0.046)\end{array}$ \\
\hline Constant & $\begin{array}{l}2.622 * * * \\
(0.093)\end{array}$ & $\begin{array}{l}2.662 * * * \\
(0.092)\end{array}$ & $\begin{array}{l}2.637 * * * \\
(0.093)\end{array}$ & $\begin{array}{l}2.649 * * * \\
(0.093)\end{array}$ & $\begin{array}{l}2.637 * * * \\
(0.093)\end{array}$ & $\begin{array}{l}2.618^{* * * *} \\
(0.092)\end{array}$ & $\begin{array}{l}2.607 * * * * \\
(0.093)\end{array}$ \\
\hline $\mathrm{R}^{2}$ & 0.384 & 0.404 & 0.398 & 0.393 & 0.390 & 0.405 & 0.393 \\
\hline Adjusted $\mathrm{R}^{2}$ & 0.372 & 0.391 & 0.385 & 0.380 & 0.376 & 0.392 & 0.380 \\
\hline Observations & 564 & 564 & 564 & 564 & 564 & 564 & 564 \\
\hline
\end{tabular}

${ }^{*} p<0.05 ; * * p<0.01 ; * * * p<0.001$

\subsubsection{Are differences in observed behavior driven by peer effects?}

In a second set of additional analysis, we explore the potential role of peer effects. Since previous studies have established the existence of peer effects in academic engagement (Tartari et al. 2014), the reader may ask whether the relationships reported above, and in our main analysis, are driven by influence between peers. That is, it may be suspected that the behavior of the individual's closest colleagues is correlated to the individual's 
Table 5 Regression results. Dependent variable: confidence to collaborate with industry

\begin{tabular}{|c|c|c|c|c|}
\hline Variables & Model 1 & Model 2 & Model 3 & Model 4 \\
\hline Gender & $\begin{array}{l}0.156^{*} \\
(0.064)\end{array}$ & $\begin{array}{l}0.153 * \\
(0.064)\end{array}$ & $\begin{array}{l}0.155 * \\
(0.064)\end{array}$ & $\begin{array}{l}0.149 * \\
(0.063)\end{array}$ \\
\hline STEM & $\begin{array}{l}-0.094 \\
(0.062)\end{array}$ & $\begin{array}{l}-0.101 \\
(0.062)\end{array}$ & $\begin{array}{l}-0.100 \\
(0.062)\end{array}$ & $\begin{array}{l}-0.090 \\
(0.062)\end{array}$ \\
\hline Master supervisor & $\begin{array}{l}-0.038 \\
(0.072)\end{array}$ & $\begin{array}{l}-0.044 \\
(0.072)\end{array}$ & $\begin{array}{l}-0.045 \\
(0.072)\end{array}$ & $\begin{array}{l}-0.001 \\
(0.072)\end{array}$ \\
\hline Doctor supervisor & $\begin{array}{l}0.083 \\
(0.092)\end{array}$ & $\begin{array}{l}0.087 \\
(0.092)\end{array}$ & $\begin{array}{l}0.104 \\
(0.092)\end{array}$ & $\begin{array}{l}0.071 \\
(0.091)\end{array}$ \\
\hline Publications & $\begin{array}{l}0.016 * \\
(0.006)\end{array}$ & $\begin{array}{l}0.016 * \\
(0.006)\end{array}$ & $\begin{array}{l}0.015 * \\
(0.006)\end{array}$ & $\begin{array}{l}0.017 * * \\
(0.006)\end{array}$ \\
\hline Public grants & $\begin{array}{l}-0.013 \\
(0.028)\end{array}$ & $\begin{array}{l}-0.012 \\
(0.028)\end{array}$ & $\begin{array}{l}-0.011 \\
(0.028)\end{array}$ & $\begin{array}{l}-0.021 \\
(0.028)\end{array}$ \\
\hline Academic rank & $\begin{array}{l}0.145 * \\
(0.072)\end{array}$ & $\begin{array}{l}0.155^{*} \\
(0.072)\end{array}$ & $\begin{array}{l}0.158 * \\
(0.072)\end{array}$ & $\begin{array}{l}0.155^{*} \\
(0.071)\end{array}$ \\
\hline Affiliation & $\begin{array}{l}0.188 * \\
(0.075)\end{array}$ & $\begin{array}{l}0.203 * * \\
(0.075)\end{array}$ & $\begin{array}{l}0.174 * \\
(0.075)\end{array}$ & $\begin{array}{l}0.193 * \\
(0.074)\end{array}$ \\
\hline Industry experience & $\begin{array}{l}0.176^{* * * *} \\
(0.030)\end{array}$ & $\begin{array}{l}0.170^{* * * *} \\
(0.030)\end{array}$ & $\begin{array}{l}0.172 * * * \\
(0.030)\end{array}$ & $\begin{array}{l}0.176^{* * *} \\
(0.030)\end{array}$ \\
\hline University mission & $\begin{array}{l}0.267 * * * \\
(0.046)\end{array}$ & $\begin{array}{l}0.231 * * * \\
(0.047)\end{array}$ & $\begin{array}{l}0.237 * * * \\
(0.047)\end{array}$ & $\begin{array}{l}0.238 * * * \\
(0.046)\end{array}$ \\
\hline University policy & $\begin{array}{l}0.277 * * * \\
(0.042)\end{array}$ & $\begin{array}{l}0.392 * * * \\
(0.058)\end{array}$ & $\begin{array}{l}0.202 * * * \\
(0.048)\end{array}$ & $\begin{array}{l}0.267 \text { *** } \\
(0.042)\end{array}$ \\
\hline U Policy*Academic rank & & $\begin{array}{l}-0.236^{* *} \\
(0.083)\end{array}$ & & \\
\hline U Policy*Affiliation & & & $\begin{array}{l}0.267 * * \\
(0.087)\end{array}$ & \\
\hline U Policy*Experience & & & & $\begin{array}{l}0.142 * * * \\
(0.038)\end{array}$ \\
\hline Constant & $\begin{array}{l}2.892 * * * \\
(0.077)\end{array}$ & $\begin{array}{l}2.907 * * * \\
(0.077)\end{array}$ & $\begin{array}{l}2.889 * * * \\
(0.077)\end{array}$ & $\begin{array}{l}2.875 * * * \\
(0.076)\end{array}$ \\
\hline $\mathrm{R}^{2}$ & 0.308 & 0.318 & 0.319 & 0.325 \\
\hline Adjusted $\mathrm{R}^{2}$ & 0.294 & 0.303 & 0.304 & 0.310 \\
\hline
\end{tabular}

$* p<0.05 ; * * p<0.01 ; * * * p<0.001$

perception of organizational factors, and that our results above are subject to omitted variable bias in the positive direction.

In view of such concerns, we introduce a basic mediation test (Judd and Kenny 1981). We introduce into model 2 of Table 3 a control variable measuring the average level of academic engagement of the individuals working in the same department as the focal individual. The results, which are available upon request, show that the peer variable is clearly significant $(p<0.01)$. Point estimates on University mission and University policy increase to $2.62(0.41)$ and $1.38(0.51)$, respectively. Compared to our main results, these are significantly higher, by a factor $>2$. We conclude that while we indeed find evidence of peer effects in academic engagement in China, there are no indications that our main results would be driven by peer effect mechanisms. 


\section{Conclusions}

Like in many other countries, the Chinese governments have taken initiatives to strengthen university-industry interactions in the hope of stimulating economic growth and regional development. In recent years, the performance of technology transfer has for example become important criteria when the Ministry of Education evaluates universities (Tang 2006). In consequence, several Chinese universities have tried to provide changes in routines, culture and policies to encourage scientists to disseminate knowledge through interactions with industry.

This study provides empirical insights into how Chinese scientists respond to their perceptions of organizational-level mission and policy in engagement with industry by scientists in Chinese universities. Our results show that scientists employed in universities with an organizational mission emphasizing economic impact are more active in academic engagement than other scientists. We also find that scientists in universities which have implemented policies to support and encourage academic engagement are indeed more active than other scientists. Thus far, our results largely confirm that the actual behavior of Chinese scientists in terms of academic engagement is related to factors addressable by university managers. We go on to analyze to what extent these basic relationships between scientists' perception of entrepreneurial mission and policy context as regards academic engagement and actual engagement applies to different groups of scientists. Specifically, we investigate junior versus senior scientists, and scientists with traditional academic careers versus scientists with personal experience from working in industry. Our results suggest that senior scientists and 'ivory tower' (i.e. traditional career) scientists are less susceptible to university policy. The patterns we find can also be described so that senior scientists are more likely than juniors to deviate in a positive sense, i.e. to engage with industry in the absence of organizational incentives and support. 'Ivory tower' scientists are more likely than scientists with past and/or present engagement outside academia to deviate in a negative sense, i.e. to defy organizational pressure to engage with industry and to abstain from utilizing support structures set up for such purposes. We argue that these results reflect a lower sensitivity to career-related incentives by senior scientists, and a lower level of matching between academic and industrial agendas for 'ivory-tower' scientists.

In further analysis, we report evidence supporting our argument that the association described above are driven by differences in attitudes (intentions and confidence) towards collaboration with industry.

In addition, we find that the results on control variables in our study were largely in line with previous studies conducted by Western scholars. This indicates that even though Chinese universities are different from Western by traditions, characteristics and national context, there are still important common patterns in university-industry interactions between the West and China.

Our study offers a set of implications for our understanding of academic engagement and technology transfer. First, our study is among the first to address academic engagement as defined by Perkmann et al. (2013) in China. This distinguishes our work from the majority of previous studies on technology transfer in China, which have been largely occupied with patenting and spin-out activities. In line with Hershberg et al. (2007), we would argue that broadening the perspective from commercialisation to academic engagement is even more relevant for understanding university-industry interactions in Chinese universities than in the West. 
Second, our research contributes to extant literature on academic knowledge transfer. Some scholars have previously investigated the association between individual industry activities and organizational context in Western countries (Bercovitz and Feldman 2008; D'Este and Patel 2007; Kalar and Antoncic 2015), but this line of studies under economic environment in developing countries are extremely limited. Our study shows that the university context is related to individual Chinese scientists' behavior in academic engagement. Specifically, our contribution lies in exploring how scientists' industrial engagement is related to how well they perceive that university missions and policies endorse and support engagement with industry. In contrast to previous research set in German and Swedish universities (Huyghe and Knockaert 2015), our study on the Chinese setting finds that these organizational factors are positively associated with industrial engagement. In contrast to recent work which did not find any associations between US biomedical scientists' perceptions of their universities mission and support for patenting and actual patenting activity (Munshaw et al. 2018), we do find such associations for academics' interactions with industrial firms..

Third, we explored moderating effects of individual factors on university context. Our results show that there are important groups of scientists for which organizational contextual factors do not seem strongly related to industry engagement. Individuals' seniority negatively moderates of the relationship between organizational-level emphasis on academic engagement and observed behavior. Furthermore, we find that scientists with stronger personal networks to industry are more sensitive to the organizational context than scientists whose careers have played out in academic environments only. We would expect these moderations to apply also in Western settings. The relatively strong element of political control in Chinese universities should, if anything, have the effect of reducing inter-individual differences. If senior and 'ivory tower'-oriented scientists are not even in this setting very susceptible to organizational-level promotion of academic engagement, it would seem plausible to assume a similar relationship to hold for academics in Western universities.

While our study is explicitly focused on academic engagement with industry, it contributes to our more general understanding of the relationship between organizational-level initiatives and incentive structures, and individual behavior in the university setting. In particular, our discussion and empirical results on moderating effects suggest that studies on university governance should pay more attention to the differences between how university reform is received by junior and senior scholars, and by scholars with different level of exante orientation towards the intended objective of the reform.

From the perspective of technology transfer practice, the results of our study provide a basis for decision making by Chinese university managers and policymakers. First, our results support the premise that organizational-level mission and policy affect academics' industrial engagement. Specifically, promotion process, unbalanced distribution of benefits and better staffed TTOs with professionals who have the proper marketing and business skills are addressable by university managers. Moreover, we find a strong positive association between how individual scientists perceive the mission of their academic environment and their level of activity in academic engagement. This result suggests that leadership plays a significant role in shaping outreach activities in Chinese universities. Second, our findings also suggest that there are important differences between groups of faculty in how strong the association between of the impacts of individual factors under external context and academic engagement really is. In particular, junior scientists are more sensitive to the university context. Drawing on this insight, policies and measures aimed at promoting academic engagement may be formulated 
specifically towards targeting juniors' demands and considerations, such as e.g. promotion assessment concerns and skill training. Moreover, scientists who lack personal industry connections or experience were found engaging little in industry activities even though the context is supportive. University managers may want to consider the establishment of more specialized institutions and assistance for this group of scientists, should they want to increase their activity in academic engagement.

\subsection{Limitations and future research}

Our study has several limitations, which also suggest directions for future research. First, in this study, we adopted measurements developed by Western scholars to study industrial relations among Chinese scientists. Even though Chinese universities share many characteristics with those in the West, specific cultural and economic conditions may still affect the generalizability of our results. From this viewpoint, it would be valuable for future research to construct studies to explicitly compare behavior and terminology regarding academic engagement activities in China and Western universities. It would also seem very interesting to subject our findings on how strongly perceptions of university mission correlates to actual behavior to comparison with Western settings, e.g. to investigate to what extent the role of university mission in China is an artifact of the country's specific tradition of governance under the patronage of the Communist Party. Second, we were in this study not able to collect sufficiently reliable data from scientists in certain subjects such as art and language. Scientists in these departments were difficult to reach, since many do not consider questions about interaction with industry as relevant for their discipline. Future research could develop other survey instruments, or utilize archival data instead of survey data to more comprehensively analyze academic engagement. Third, we have in our study no way of testing to what extent our results are driven by differences in recruitment. More entrepreneurially oriented universities may tend to recruit more entrepreneurially oriented scientists. Such individuals may be different both in terms of behavior and in attitudes towards academic engagement than the average academic. While we do not see strong reasons to believe that the interaction effects that constitute the bulk of our results would be driven by such differences, both sorting-though-recruitment and post-recruitment adaption to perceptions about university mission may generate evidence supporting our first hypothesis. Further research should seek to disentangle the different mechanisms.

Funding Funding was provided by Riksbankens Jubileumsfond (FSK15-1059:1).

Open Access This article is distributed under the terms of the Creative Commons Attribution 4.0 International License (http://creativecommons.org/licenses/by/4.0/), which permits unrestricted use, distribution, and reproduction in any medium, provided you give appropriate credit to the original author(s) and the source, provide a link to the Creative Commons license, and indicate if changes were made.

\section{Appendix 1: Notes on methodology}

See Tables 6, 7 and 8. 


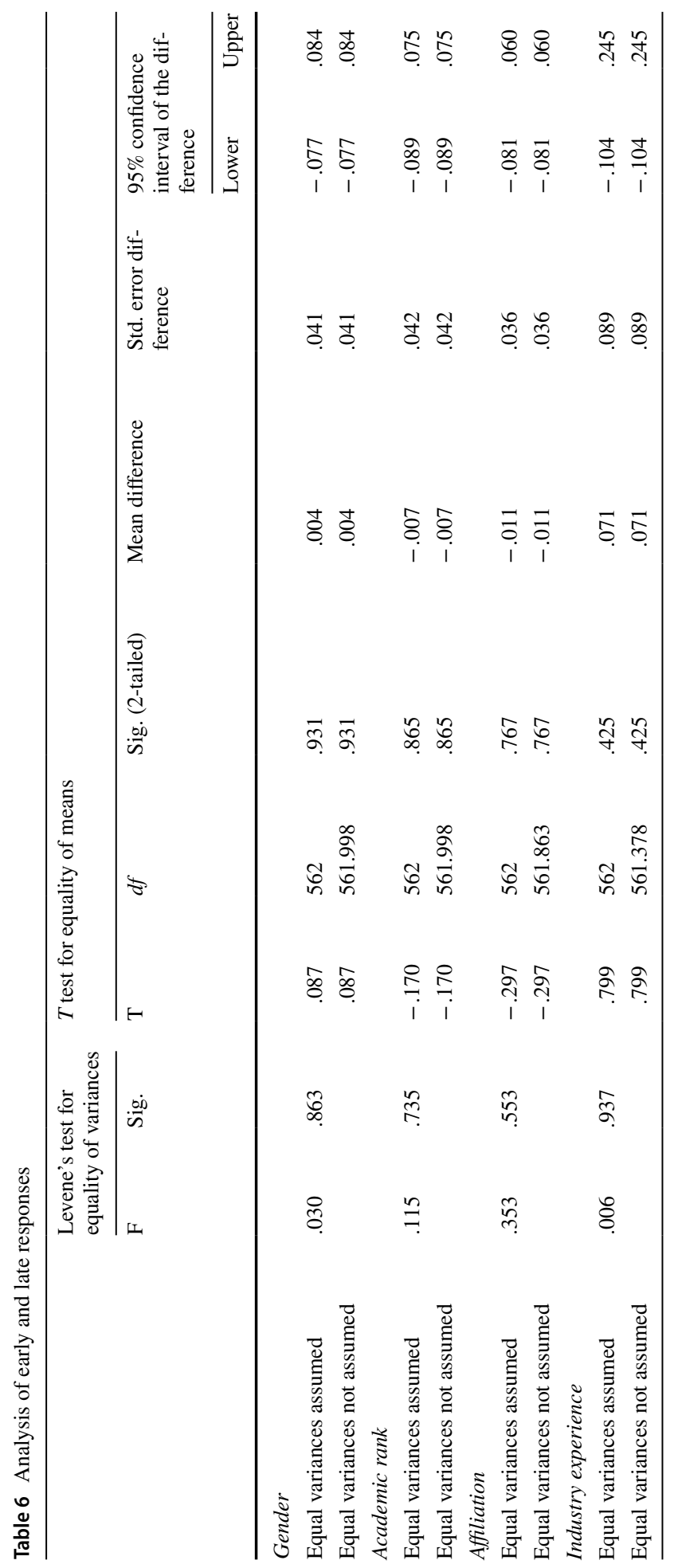




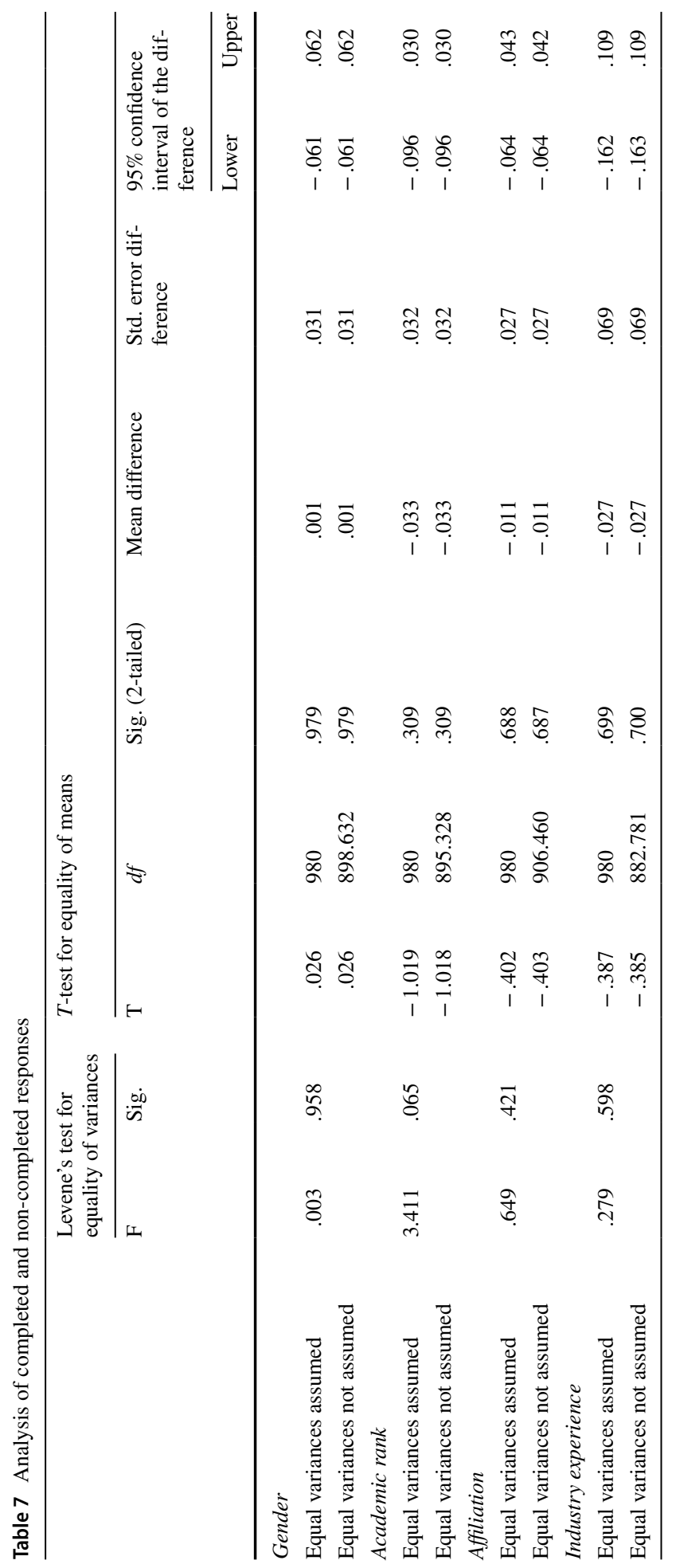


Table 8 Academic engagement scale. Adapted from D'Este and Patel (2007)

How frequently have you been engaged in the following types of activities in 2014 and Difficulty degree 2015 ?

1. A new joint research agreement sponsored by industry (original research work undertaken by both partners)

2. A new joint research agreement sponsored by third party (original research work $\quad 0.436$ undertaken by both partners)

3. Working with industry personnel that resulted in a patent or copyright $\quad 0.628$

4. A new consultancy agreement (no original research undertaken) $\quad 0.298$

$\begin{array}{ll}\text { 5. Providing advices to industry } & 0.543\end{array}$

6. Training of company employees (through course enrolment or through temporary $\quad 0.498$ personnel exchanges)

7. Postgraduate training in the company (e.g. joint supervision of $\mathrm{PhDs}$ )

8. A new contract research agreement (original research work done by University alone) 0.418

9. Creation of new physical facilities with industry funding (e.g. new laboratory, other $\quad 0.640$ building on campus)

10. Attendance at conferences with industry and university participation

11. Attendance at industry sponsored meetings

\section{Appendix 2: Robustness tests}

See Tables 9, 10. 


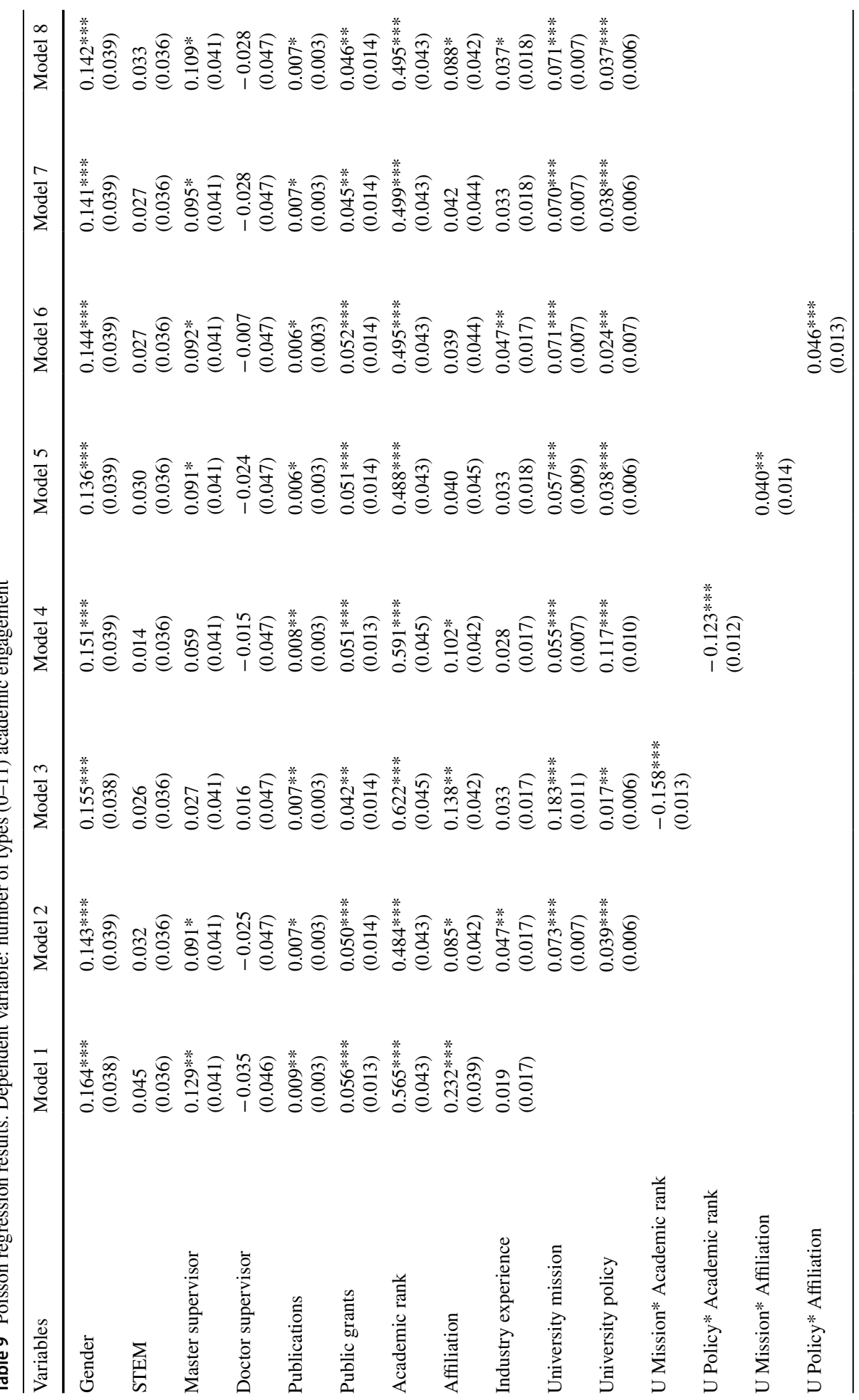




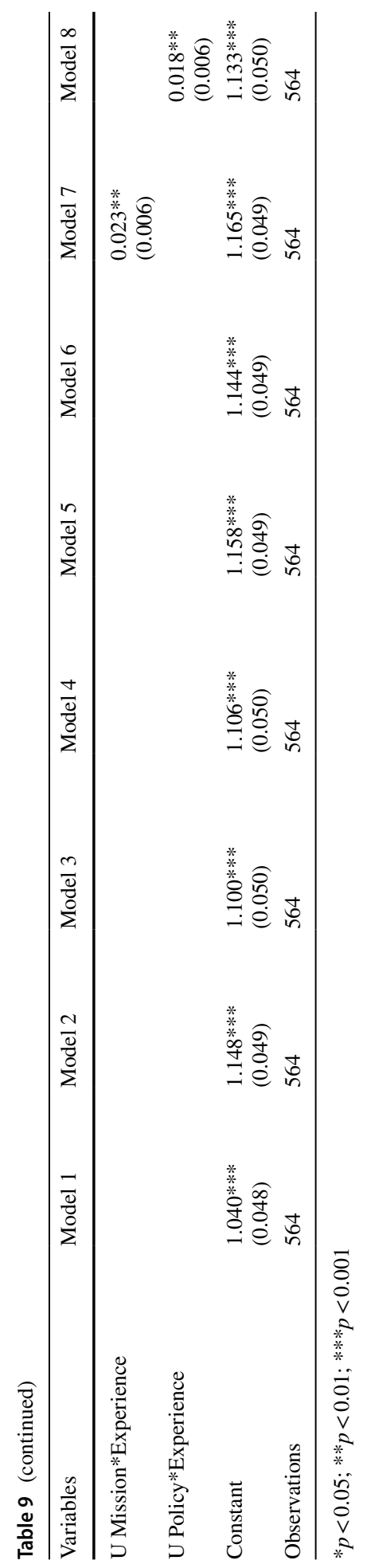


Table 10 Results on industry funding Source: China University Science and Technology Annual Report (Ministry of Education 2016)

\begin{tabular}{|c|c|c|c|c|c|}
\hline Variables & Model 1 & Model 2 & Model 3 & Model 4 & Model 5 \\
\hline Gender & $\begin{array}{l}1.796 * * \\
(0.635)\end{array}$ & $\begin{array}{l}1.834 * * \\
(0.604)\end{array}$ & $\begin{array}{l}1.887 * * \\
(0.602)\end{array}$ & $\begin{array}{l}1.742 * * \\
(0.602)\end{array}$ & $\begin{array}{l}1.738 * * \\
(0.600)\end{array}$ \\
\hline STEM & $\begin{array}{l}0.048 \\
(0.615)\end{array}$ & $\begin{array}{l}0.067 \\
(0.584)\end{array}$ & $\begin{array}{l}0.136 \\
(0.583)\end{array}$ & $\begin{array}{l}0.107 \\
(0.581)\end{array}$ & $\begin{array}{l}0.013 \\
(0.580)\end{array}$ \\
\hline Master supervisor & $\begin{array}{l}1.926 * * \\
(0.711)\end{array}$ & $\begin{array}{l}1.225 \\
(0.682)\end{array}$ & $\begin{array}{l}1.086 \\
(0.682)\end{array}$ & $\begin{array}{l}1.181 \\
(0.678)\end{array}$ & $\begin{array}{l}1.437 * \\
(0.679)\end{array}$ \\
\hline Doctor supervisor & $\begin{array}{l}1.214 \\
(0.915)\end{array}$ & $\begin{array}{l}1.425 \\
(0.870)\end{array}$ & $\begin{array}{l}1.590 \\
(0.869)\end{array}$ & $\begin{array}{l}1.564 \\
(0.867)\end{array}$ & $\begin{array}{l}1.412 \\
(0.862)\end{array}$ \\
\hline Publications & $\begin{array}{l}0.178 * * \\
(0.063)\end{array}$ & $\begin{array}{l}0.127 * \\
(0.060)\end{array}$ & $\begin{array}{l}0.133^{*} \\
(0.060)\end{array}$ & $\begin{array}{l}0.124 * \\
(0.060)\end{array}$ & $\begin{array}{l}0.128^{*} \\
(0.060)\end{array}$ \\
\hline Public grants & $\begin{array}{l}0.729 * \\
(0.281)\end{array}$ & $\begin{array}{l}0.542 * \\
(0.268)\end{array}$ & $\begin{array}{l}0.548 * \\
(0.267)\end{array}$ & $\begin{array}{l}0.561 * \\
(0.267)\end{array}$ & $\begin{array}{l}0.524 * \\
(0.266)\end{array}$ \\
\hline Academic rank & $\begin{array}{l}3.153 * * * \\
(0.703)\end{array}$ & $\begin{array}{l}3.124 * * * \\
(0.669)\end{array}$ & $\begin{array}{l}5.614 * * * \\
(1.252)\end{array}$ & $\begin{array}{l}3.110 * * * \\
(0.665)\end{array}$ & $\begin{array}{l}3.119 \text { *** } \\
(0.663)\end{array}$ \\
\hline Affiliation & $\begin{array}{l}4.620 * * * \\
(0.736)\end{array}$ & $\begin{array}{l}3.978 * * * \\
(0.704)\end{array}$ & $\begin{array}{l}4.129 * * * \\
(0.704)\end{array}$ & $\begin{array}{l}1.114 * * * \\
(1.308)\end{array}$ & $\begin{array}{l}3.941 * * * \\
(0.698)\end{array}$ \\
\hline Industry experience & $\begin{array}{l}0.579 * \\
(0.292)\end{array}$ & $\begin{array}{l}0.649 * \\
(0.277)\end{array}$ & $\begin{array}{l}0.621 * \\
(0.277)\end{array}$ & $\begin{array}{l}0.657 * \\
(0.276)\end{array}$ & $\begin{array}{l}-1.034 \\
(0.592)\end{array}$ \\
\hline Industry funding & & $\begin{array}{l}0.264 * * * \\
(0.034)\end{array}$ & $\begin{array}{l}0.324 * * * \\
(0.042)\end{array}$ & $\begin{array}{l}0.194 * * * \\
(0.043)\end{array}$ & $\begin{array}{l}-0.096 \\
(0.117)\end{array}$ \\
\hline Industry funding*Academic rank & & & $\begin{array}{l}-0.160 * \\
(0.068)\end{array}$ & & \\
\hline Industry funding*Affiliation & & & & $\begin{array}{l}0.173 * \\
(0.067)\end{array}$ & \\
\hline Industry funding*Experience & & & & & $\begin{array}{l}0.112 * \\
(0.035)\end{array}$ \\
\hline Constant & $\begin{array}{l}-0.569 \\
(1.104)\end{array}$ & $\begin{array}{l}-3.839 * * \\
(1.131)\end{array}$ & $\begin{array}{l}-4.636^{* * * *} \\
(1.177)\end{array}$ & $\begin{array}{l}-2.731^{*} \\
(1.204)\end{array}$ & $\begin{array}{l}1.517 \\
(2.011)\end{array}$ \\
\hline $\mathrm{R}^{2}$ & 0.297 & 0.366 & 0.372 & 0.374 & 0.378 \\
\hline Adjusted $\mathrm{R}^{2}$ & 0.286 & 0.355 & 0.360 & 0.361 & 0.365 \\
\hline Observations & 564 & 564 & 564 & 564 & 564 \\
\hline
\end{tabular}

$* p<0.05 ; * * p<0.01 ; * * * p<0.001$

The variable' Industry funding' captures total industrial funding for a university divided by the number of R\&D personnel

\section{References}

Abreu, M., \& Grinevich, V. (2013). The nature of academic entrepreneurship in the UK: Widening the focus on entrepreneurial activities. Research Policy, 42(2), 408-422.

Ambos, T. C., Mäkelä, K., Birkinshaw, J., \& D’Este, P. (2008). When does university research get commercialized? Creating ambidexterity in research institutions. Journal of Management Studies, 45(8), 1424-1447.

Aschhoff, B., \& Grimpe, C. (2013). Peer effects and academics' industry involvement: The role of age in professional imprinting. Academy of Management Proceedings, 1, 12179.

Azagra-Caro, J. M. (2007). What type of faculty member interacts with what type of firm? Some reasons for the delocalisation of university-industry interaction. Technovation, 27(11), 704-715. 
Bart, C. K. (1996). High tech firms: Does mission matter? Journal of High Technology Management Research, 7(2), 209-225.

Bekkers, R., \& Freitas, I. M. B. (2008). Analysing knowledge transfer channels between universities and industry: To what degree do sectors also matter? Research Policy, 37(10), 1837-1853.

Bercovitz, J., \& Feldman, M. (2006). Entpreprenerial universities and technology transfer: A conceptual framework for understanding knowledge-based economic development. The Journal of Technology Transfer, 31(1), 175-188.

Bercovitz, J., \& Feldman, M. (2008). Academic entrepreneurs: Organizational change at the individual level. Organization Science, 19(1), 69-89.

Boardman, P. C. (2008). Beyond the stars: The impact of affiliation with university biotechnology centers on the industrial involvement of university scientists. Technovation, 28(5), 291-297.

Boardman, P. C., \& Ponomariov, B. L. (2009). University researchers working with private companies. Technovation, 29(2), 142-153.

Bonaccorsi, A., Daraio, C., \& Geuna, A. (2010). Universities in the new knowledge landscape: Tensions, challenges change-An introduction. Minerva, 48(1), 1-4.

Bozeman, B., \& Gaughan, M. (2007). Impacts of grants and contracts on academic researchers' interactions with industry. Research Policy, 36(5), 694-707.

Broström, A., McKelvey, M., \& Sandström, C. (2009). Investing in localized relationships with universities: What are the benefits for R\&D subsidiaries of multinational enterprises? Industry and Innovation, 16(1), 59-78.

Caldera, A., \& Debande, O. (2010). Performance of Spanish universities in technology transfer: An empirical analysis. Research Policy, 39(9), 1160-1173.

Cohen, W. M., Florida, R., Randazzese, L., \& Walsh, J. (1998). Industry and the academy: Uneasy partners in the cause of technological advance. Challenges to Research Universities, 171(200), 59.

Cohen, W. M., Nelson, R. R., \& Walsh, J. P. (2002). Links and impacts: The influence of public research on industrial R\&D. Management Science, 48(1), 1-23.

Colyvas, J. A., \& Powell, W. W. (2006). Roads to institutionalization: The remaking of boundaries between public and private science. Research in Organizational Behavior, 27(06), 305-353.

Corley, E., \& Gaughan, M. (2005). Scientists' participation in university research centers: What are the gender differences? The Journal of Technology Transfer, 30(4), 371-381.

Cronbach, L. J. (1951). Coefficient alpha and the internal structure of tests. Psychometrika, 16(3), $297-334$.

D'Este, P., \& Patel, P. (2007). University-industry linkages in the UK: What are the factors underlying the variety of interactions with industry? Research Policy, 36(9), 1295-1313.

D'Este, P., \& Perkmann, M. (2011). Why do academics engage with industry? The entrepreneurial university and individual motivations. The Journal of Technology Transfer, 36(3), 316-339.

David, W., \& Fahey, L. (2000). Diagnosing cultural barriers to knowledge management. The Academy of Management Executive, 14(4), 113-127.

Etzkowitz, H. (2003). Research groups as 'quasi-firms': The invention of the entrepreneurial university. Research Policy, 32(1), 109-121.

Etzkowitz, H. (2004). The evolution of the entrepreneurial university. International Journal of Technology \& Globalisation, 1(1), 64-77.

Etzkowitz, H., Webster, A., \& Healey, P. (1998). Capitalizing knowledge: New intersections of industry and academia. Albany: Suny Press.

Feller, I., Ailes, C. P., \& Roessner, J. D. (2002). Impacts of research universities on technological innovation in industry: Evidence from engineering research centers. Research Policy, 31(3), 457-474.

Fornell, C., \& Larcker, D. F. (1981). Evaluating structural equation models with unobservable variables and measurement error. Journal of Marketing Research, 18(1), 39-50.

Friedman, J., \& Silberman, J. (2003). University technology transfer: Do incentives, management, and location matter? The Journal of Technology Transfer, 28(1), 17-30.

Giuliani, E., Morrison, A., Pietrobelli, C., \& Rabellotti, R. (2010). Who are the researchers that are collaborating with industry? An analysis of the wine sectors in Chile, South Africa and Italy. Research Policy, 39(6), 748-761.

Gold, T., Guthrie, D., \& Wank, D. (2002). Social connections in China: Institutions, culture, and the changing nature of guanxi. Cambridge: Cambridge University Press.

Gregorio, D. D., \& Shane, S. (2003). Why do some universities generate more start-ups than others? Research Policy, 32(2), 209-227.

Guerrero, M., \& Urbano, D. (2012). The development of an entrepreneurial university. The Journal of Technology Transfer, 37(1), 43-74.

Haeussler, C., \& Colyvas, J. A. (2011). Breaking the ivory tower: Academic entrepreneurship in the life sciences in UK and Germany. Research Policy, 40(1), 41-54. 
Hair, J. F., Black, W. C., Babin, B. J., \& Anderson, R. E. (2010). Multivariate data analysis: A global perspective. Upper Saddle River: Pearson Prentice Hall.

Hershberg, E., Nabeshima, K., \& Yusuf, S. (2007). Opening the ivory tower to business: Universityindustry linkages and the development of knowledge-intensive clusters in Asian cities. World Development, 35(6), 931-940.

Hetzner, W. A., Gidley, T. R., \& Gray, D. O. (1989). Cooperative research and rising expectations: Lessons from NSF's industry/university cooperative research centers. Technology in Society, 11(3), 335-345.

Hunter, E. M., Perry, S. J., \& Currall, S. C. (2011). Inside multi-disciplinary science and engineering research centers: The impact of organizational climate on invention disclosures and patents. Research Policy, 40(9), 1226-1239.

Huyghe, A., \& Knockaert, M. (2015). The influence of organizational culture and climate on entrepreneurial intentions among research scientists. The Journal of Technology Transfer, 40(1), 138-160.

Iorio, R., Labory, S., \& Rentocchini, F. (2017). The importance of pro-social behaviour for the breadth and depth of knowledge transfer activities: An analysis of Italian academic scientists. Research Policy, 46(2), 497-509.

Jain, S., George, G., \& Maltarich, M. (2009). Academics or entrepreneurs? Investigating role identity modification of university scientists involved in commercialization activity. Research Policy, 38(6), 922-935.

Jensen, R., \& Thursby, M. (2003). Proofs and prototypes for sale: The licensing of university inventions. American Economic Review, 91(1), 240-259.

Judd, C. M., \& Kenny, D. A. (1981). Process analysis estimating mediation in treatment evaluations. Evaluation Review, 5(5), 602-619.

Kalar, B., \& Antoncic, B. (2015). The entrepreneurial university, academic activities and technology and knowledge transfer in four European countries. Technovation, 36-37, 1-11.

Kenney, M., \& Goe, W. R. (2004). The role of social embeddedness in professorial entrepreneurship: A comparison of electrical engineering and computer science at UC Berkeley and Stanford. Research Policy, 33(5), 691-707.

Lam, A. (2007). Knowledge networks and careers: academic scientists in industry-university links. Journal of Management Studies, 44(6), 993-1016.

Lam, A. (2010). From 'ivory tower traditionalists' to 'entrepreneurial scientists'? Social Studies of Science: An International Review of Research in the Social Dimensions of Science and Technology, 40(2), 307-340.

Link, A. N., \& Siegel, D. S. (2007). Innovation, entrepreneurship, and technological change. Oxford: Oxford University Press.

Link, A. N., Siegel, D. S., \& Bozeman, B. (2007). An empirical analysis of the propensity of academics to engage in informal university technology transfer. Industrial and Corporate Change, 16(4), 641-655.

Liu, H., \& Jiang, Y. (2001). Technology transfer from higher education institutions to industry in China: Nature and implications. Technovation, 21(3), 175-188.

Lööf, H., \& Broström, A. (2008). Does knowledge diffusion between university and industry increase innovativeness? The Journal of Technology Transfer, 33(1), 73-90.

McKelvey, M., \& Ljungberg, D. (2017). How public policy can stimulate the capabilities of firms to innovate in a traditional industry through academic engagement: The case of the Swedish food industry. $R \& D$ Management, 47(4), 534-544.

Ministry of Education. (2016). China University science and technology annual report. Beijing: Higher Education Press.

Motohashi, K. (2006). China's national innovation system reform and growing science industry linkage. Asian Journal of Technology Innovation, 14(2), 49-65.

Munshaw, S., Lee, S. H., Phan, P. H., \& Marr, K. A. (2018). The influence of human capital and perceived university support on patent applications of biomedical investigators. The Journal of Technology Transfer (forthcoming).

O'Shea, R. P., Chugh, H., \& Allen, T. J. (2008). Determinants and consequences of university spinoff activity: A conceptual framework. The Journal of Technology Transfer, 33(6), 653-666.

Oliver, C. (1991). Strategic responses to institutional processes. Academy of Management Review, 16(1), $145-179$.

O'Shea, R. P., Allen, T. J., Chevalier, A., \& Roche, F. (2005). Entrepreneurial orientation, technology transfer and spinoff performance of U.S. universities. Research Policy, 34(7), 994-1009.

O'Shea, R. P., Allen, T. J., Morse, K. P., O'Gorman, C., \& Roche, F. (2007). Delineating the anatomy of an entrepreneurial university: The Massachusetts Institute of Technology experience. R\&D Management, 37(1), 1-16. 
Perkmann, M., Tartari, V., McKelvey, M., Autio, E., Broström, A., D’Este, P., et al. (2013). Academic engagement and commercialisation: A review of the literature on university-industry relations. Research Policy, 42(2), 423-442.

Philpott, K., Dooley, L., O'Reilly, C., \& Lupton, G. (2011). The entrepreneurial university: Examining the underlying academic tensions. Technovation, 31(4), 161-170.

Ponomariov, B. L. (2008). Effects of university characteristics on scientists' interactions with the private sector: An exploratory assessment. The Journal of Technology Transfer, 33(5), 485-503.

Roberts, E. B. (1991). Entrepreneurs in high technology: Lessons from MIT and beyond. Oxford: Oxford University Press.

Schartinger, D., Schibany, A., \& Gassler, H. (2001). Interactive relations between universities and firms: Empirical evidence for Austria. The Journal of Technology Transfer, 26(3), 255-268.

Scott, W. R. (1987). The adolescence of institutional theory. Administrative Science Quarterly, 32(4), $493-511$.

Scott, W. R. (2013). Institutions and organizations: Ideas, interests, and identities. Thousand Oaks: Sage.

Shi, Y., Ma, M., Liu, X., \& Xie, J. (2008). Indigenous innovation capabilities of manufacturing firms in Hunan Province (hunan gongye qiye zizhu chuangxin nengli yanjiu). Entrepreneurs, 9, 10-12.

Siegel, D. S., Waldman, D., \& Link, A. (2003). Assessing the impact of organizational practices on the relative productivity of university technology transfer offices: An exploratory study. Research Policy, 32(1), 27-48.

Slaughter, S., \& Leslie, L. L. (1997). Academic capitalism: Politics, policies, and the entrepreneurial university. Academic Freedom, 23(100), 221-228.

Slaughter, S., \& Leslie, L. L. (2001). Expanding and elaborating the concept of academic capitalism. Organization, 8(2), 154-161.

Smith, M., Heady, R. B., Carson, P. P., \& Carson, K. D. (2001). Do missions accomplish their missions? An exploratory analysis of mission statement content and organizational longevity. The Journal of Applied Management and Entrepreneurship, 6(1), 75-96.

Stuart, Toby E., \& Ding, Waverly W. (2006). When do scientists become entrepreneurs? The social structural antecedents of commercial activity in the academic life sciences. American Journal of Sociology, 112(1), 97-144.

Sun, J. Y., \& Gu, Q. (2017). For public causes or personal interests? Examining public service motives in the Chinese context. Asia Pacific Journal of Human Resources, 55(4), 476-497.

Swales, J. M., \& Rogers, P. S. (1995). Discourse and the projection of corporate culture: The mission statement. Discourse \& Society, 6(2), 223-242.

Szulanski, G. (1996). Exploring internal stickiness: Impediments to the transfer of best practice within the firm. Strategic Management Journal, 17(S2), 27-43.

Tang, M. F. (2006). A comparative study on the role of National Technology Transfer Centers in different Chinese universities. In Globalics Conference, Trivandrum, India.

Tartari, V., Perkmann, M., \& Salter, A. (2014). In good company: The influence of peers on industry engagement by academic scientists. Research Policy, 43(7), 1189-1203.

Thursby, J. G., \& Thursby, M. C. (2004). Are faculty critical? Their role in university-industry licensing. Contemporary Economic Policy, 22(2), 162-178.

Tolbert, P. S., \& Zucker, L. G. (1999). The institutionalization of institutional theory. In S. R. Clegg, S. Clegg, \& C. Hardy (Eds.), Studying organization: Theory \& method (pp. 175-190). London: Sage.

Tsui, A. S., \& Farh, J.-L. L. (1997). Where guanxi matters: Relational demography and guanxi in the Chinese context. Work and Occupations, 24(1), 56-79.

Wood, F. (1990). Factors influencing research performance of university academic staff. Higher Education, 19(1), 81-100.

Wright, M., Clarysse, B., Lockett, A., \& Knockaert, M. (2008). Mid-range universities' linkages with industry: Knowledge types and the role of intermediaries. Research Policy, 37(8), 1205-1223.

$\mathrm{Wu}, \mathrm{W}$. (2010). Managing and incentivizing research commercialization in Chinese Universities. The Journal of Technology Transfer, 35(2), 203-224.

Wu, W., \& Zhou, Y. (2012). The third mission stalled? Universities in China's technological progress. The Journal of Technology Transfer, 37(6), 812-827.

Zhou, Y. (2005). The making of an innovative region from a centrally planned economy: Institutional evolution in Zhongguancun Science Park in Beijing. Environment and Planning A, 37(6), 1113-1134.

Zhou, Y., Sun, Y., Wei, Y. H. D., \& Lin, G. C. S. (2011). De-centering 'spatial fix'-Patterns of territorialization and regional technological dynamism of ICT hubs in China. Journal of Economic Geography, 11(1), 119-150. 